\title{
Relations between erythemal UV dose, global solar radiation, total ozone column and aerosol optical depth at Uccle, Belgium
}

\author{
V. De Bock, H. De Backer, R. Van Malderen, A. Mangold, and A. Delcloo \\ Royal Meteorological Institute of Belgium, Ringlaan 3, 1180 Brussels, Belgium \\ Correspondence to: V. De Bock (veerle.debock@meteo.be)
}

Received: 25 April 2014 - Published in Atmos. Chem. Phys. Discuss.: 24 June 2014

Revised: 7 October 2014 - Accepted: 7 October 2014 - Published: 20 November 2014

\begin{abstract}
At Uccle, Belgium, a long time series (1991-2013) of simultaneous measurements of erythemal ultraviolet $(\mathrm{UV})$ dose $\left(S_{\text {ery }}\right)$, global solar radiation $\left(S_{\mathrm{g}}\right)$, total ozone column $\left(Q_{\mathrm{O}_{3}}\right)$ and aerosol optical depth $\left(\tau_{\text {aer }}\right)$ (at $320.1 \mathrm{~nm}$ ) is available, which allows for an extensive study of the changes in the variables over time. Linear trends were determined for the different monthly anomalies time series. $S_{\text {ery }}, S_{\mathrm{g}}$ and $Q_{\mathrm{O}_{3}}$ all increase by respectively 7,4 and $3 \%$ per decade. $\tau_{\text {aer }}$ shows an insignificant negative trend of $-8 \%$ per decade. These trends agree with results found in the literature for sites with comparable latitudes. A change-point analysis, which determines whether there is a significant change in the mean of the time series, is applied to the monthly anomalies time series of the variables. Only for $S_{\text {ery }}$ and $Q_{\mathrm{O}_{3}}$, was a significant change point present in the time series around February 1998 and March 1998, respectively. The change point in $Q_{\mathrm{O}_{3}}$ corresponds with results found in the literature, where the change in ozone levels around 1997 is attributed to the recovery of ozone. A multiple linear regression (MLR) analysis is applied to the data in order to study the influence of $S_{\mathrm{g}}, Q_{\mathrm{O}_{3}}$ and $\tau_{\text {aer }}$ on $S_{\text {ery }}$. Together these parameters are able to explain $94 \%$ of the variation in $S_{\text {ery }}$. Most of the variation (56\%) in $S_{\text {ery }}$ is explained by $S_{\mathrm{g}}$. The regression model performs well, with a slight tendency to underestimate the measured $S_{\text {ery }}$ values and with a mean absolute bias error (MABE) of $18 \%$. However, in winter, negative $S_{\text {ery }}$ are modeled. Applying the MLR to the individual seasons solves this issue. The seasonal models have an adjusted $R^{2}$ value higher than 0.8 and the correlation between modeled and measured $S_{\text {ery }}$ values is higher than 0.9 for each season. The summer model gives the best performance, with an absolute mean error of only $6 \%$. However, the seasonal regression models do
\end{abstract}

not always represent reality, where an increase in $S_{\text {ery }}$ is accompanied with an increase in $Q_{\mathrm{O}_{3}}$ and a decrease in $\tau_{\text {aer }}$. In all seasonal models, $S_{\mathrm{g}}$ is the factor that contributes the most to the variation in $S_{\text {ery }}$, so there is no doubt about the necessity to include this factor in the regression models. The individual contribution of $\tau_{\text {aer }}$ to $S_{\text {ery }}$ is very low, and for this reason it seems unnecessary to include $\tau_{\text {aer }}$ in the MLR analysis. Including $Q_{\mathrm{O}_{3}}$, however, is justified to increase the adjusted $R^{2}$ and to decrease the MABE of the model.

\section{Introduction}

The discovery of the Antarctic ozone hole in the mid-1980s triggered an increased scientific interest in the state of stratospheric ozone levels on a global scale (Garane et al., 2006). The ozone depletion not only occurred above the Antarctic; there is strong evidence that stratospheric ozone also diminished above midlatitudes (Bartlett and Webb, 2000; Kaurola et al., 2000; Smedley et al., 2012). While ozone depletion continued in the 2000s over the polar regions, it has leveled off at midlatitudes, although ozone amounts still remain lower compared to the amounts in the 1970s (Garane et al., 2006). Stratospheric ozone is expected to recover in response to the ban on ozone-depleting substances (ODSs) agreed upon in the Montreal Protocol in 1987 (WMO, 2006; Fitzka et al., 2012). However, it is difficult to predict future changes in ozone as the predictions suffer from uncertainties caused by the general climate change; numerical errors of simulation models; and by human behavior, which is not well controllable in several parts of the world. The decline in stratospheric ozone has shifted the focus of the scientific community and the general public towards the variability of 
surface UV irradiance (Krzýscin et al., 2011). If all other factors influencing UV irradiance remain stable, reductions in stratospheric ozone would lead to an increase in UV irradiance at the ground, particularly at wavelengths below $320 \mathrm{~nm}$ (Garane et al., 2006). Increases of UV irradiance in response to the ozone decline have already been reported for different sites during the 1990s (Garane et al., 2006, and references therein).

The possible increase in UV irradiance raises concerns because of its adverse health and environmental effects. Overexposure can lead to the development of skin cancers, cataract, skin aging and the suppression of the immune system (Rieder et al., 2008; Cordero et al., 2009). UV irradiance also has adverse effects on terrestrial plants (Tevini and Teramura, 1989; Cordero et al., 2009) and on other elements of the biosphere (Diffey, 1991). On the other hand, UV radiation does enable the production of vitamin $\mathrm{D}$ in the skin, which is positively linked to health effects as it supports bone health and may decrease the risk of several internal cancers (United Nations Environment Programme, 2010). It is important to assess the changes in UV irradiance over prolonged periods of time. Not only do adverse health and environmental effects often relate to long-term exposure (from years to a lifetime); also the timescales of the atmospheric processes that are involved, such as ozone depletion and recovery, are beyond decades (Chubarova, 2008; den Outer et al., 2010).

Physically, UV trends can only be detected from direct measurements on Earth. Reconstructed data can be based on proxy data such as the abundance of ozone, solar irradiance, sunshine duration or regional reflectivity of the Earth-atmosphere system measured from space (Lindfors et al., 2003). Different sorts of reconstruction models have been used in several studies. They all use various kinds of statistical or model approaches and different meteorological or irradiance data sets (Lindfors et al., 2007; Chubarova, 2008; Rieder et al., 2010; den Outer et al., 2010; Bais et al., 2011). Techniques are either based on modeling of clearsky UV irradiance or on empirical relationships between surface UV irradiance and the factors influencing the penetration of UV irradiance through the atmosphere (Kaurola et al., 2000; Trepte and Winkler, 2004). In addition to the reconstruction studies, changes in surface UV irradiance have also been studied using ground-based measurements at different locations (e.g., den Outer et al., 2000; Sasaki et al., 2002; Bernhard et al., 2006; Fitzka et al., 2012; Zerefos et al., 2012; Eleftheratos et al., 2014) or even in combination with satellite retrievals (Herman et al., 1996; Matthijsen et al., 2000; Kalliskota et al., 2000; Ziemke et al., 2000; Zerefos et al., 2001; Fioletov et al., 2004; Williams et al., 2004). Some studies combine both models and observations to investigate possible UV irradiance changes (e.g., Kaurola et al., 2000).

Not only stratospheric ozone influences the intensity of UV irradiance reaching the surface of the Earth. Long-term changes in solar elevation, tropospheric ozone, clouds, Rayleigh scattering on air molecules, surface albedo, aerosols, absorption by trace gases and changes in the distance between the Sun and the Earth can lead to trends in UV irradiance (WMO, 2006). Some studies show that increased amounts of aerosols and trace gases from industrial emissions, which absorb UV irradiance in the troposphere, could even compensate for the UV effects caused by the stratospheric ozone decline (Krzýscin et al., 2011; Fitzka et al., 2012). Clouds induce more variability in surface UV irradiance than any other geophysical factor, besides the solar elevation, but their effects depend very much on local conditions (Krzýscin et al., 2011). Surface albedo is determined mostly by snow amount and snow depth (Rieder et al., 2010) and plays a significant role at high-altitude and highlatitude sites, where UV irradiance can be strongly enhanced due to multiple occurrences of scattering and reflection between snow-covered ground and the atmosphere (Fitzka et al., 2012). Several studies have been conducted to quantify the effects of the abovementioned variables on the amount of UV irradiance reaching the ground, and many of them have done so by constructing empirical models with UV irradiance (or a related quantity) as a dependent variable (Díaz et al., 2000; Fioletov et al., 2001; de La Casinière et al., 2002; Foyo-Moreno et al., 2007; Antón et al., 2009; De Backer, 2009; Huang et al., 2011; Krishna Prasad et al., 2011; El Shazly et al., 2012).

At Uccle, Belgium, simultaneous measurements of erythemal UV dose, global solar radiation, total ozone column and aerosol optical depth at $320.1 \mathrm{~nm}$ are available for a time period of 23 years (1991-2013). The time series is long enough to allow for reliable determination of significant changes (a minimum of 15 years is required as shown in Weatherhead et al., 1998, and Glandorf et al., 2005). The availability of the simultaneous time series allows an extensive analysis in which three analysis techniques (linear trend analysis, change-point analysis and multiple linear regression analysis) will be combined in order to increase our insights on the relations between the variables. First, a linear trend analysis will be applied to the monthly anomalies of the time series (both on a daily and seasonal timescale), and the results will be compared with results found in the literature. Monthly anomalies are used here to reduce the influence of the seasonal cycle on the analysis and are calculated by subtracting the long-term monthly mean from the individual monthly means. The monthly anomalies time series will also be the subject of change-point analysis, where the homogeneity of the time series will be investigated. Finally, the multiple linear regression (MLR) technique (with daily erythemal UV doses as the dependent variable and daily values of global solar radiation, total ozone column and aerosol optical depth at $320.1 \mathrm{~nm}$ as explanatory variables) will allow us to study the influence of the explanatory variables on the dependent variable on a daily and seasonal basis. 


\section{Data}

In this study, the (all-sky) erythemal UV dose, (all-sky) global solar radiation, total ozone column and (clear-sky) aerosol optical depth at $320.1 \mathrm{~nm}$ are investigated over a time period of 23 years (1991-2013). These measurements are performed at Uccle, Belgium $\left(50^{\circ} 48^{\prime} \mathrm{N}, 4^{\circ} 21^{\prime} \mathrm{E}\right.$, $100 \mathrm{~m}$ a.s.l.), a residential suburb of Brussels located about $100 \mathrm{~km}$ from the North Sea shore.

\subsection{Daily erythemal UV dose}

In 1989, the Brewer spectrophotometer instrument \#016, a single monochromator, was equipped with a UV-B monitor (De Backer, 2009). This is an optical assembly which enables the Brewer to measure UV-B irradiance using a thin disc of Teflon as a transmitting diffuser (SCI TEC Brewer \#016 manual, 1988). The Brewer measures the horizontal spectral UV irradiance with a spectral resolution of approximately $0.55 \mathrm{~nm}$, full width at half maximum. The instrument performs UV scans from 290 to $325 \mathrm{~nm}$ with $0.5 \mathrm{~nm}$ wavelength steps (Fioletov et al., 2002). The erythemal irradiances are calculated using the erythemal action spectrum as determined by the Commission Internationale de l'Eclairage and are integrated to daily erythemal doses (De Backer, 2009). For wavelengths above $325 \mathrm{~nm}$, for which Brewer\#016 does not provide data, the intensities are extrapolated using a theoretical spectrum weighted by the intensity at $325 \mathrm{~nm}$. This is justified by the fact that, at those wavelengths, the UV intensity is no longer strongly dependent on ozone and the erythemal weighting function is low. For the calculation of the daily sum, a linear interpolation between the different measurement points is performed. When there is an interruption of $2 \mathrm{~h}$ or more between the measurements between sunrise and sunset, the calculated daily sum is rejected. The data (in joules per square meter, $\mathrm{J} \mathrm{m}^{-2}$ ) are available on a regular basis from 1991. The instrument is calibrated with 50W lamps on a monthly basis and with $1000 \mathrm{~W}$ lamps during intercomparisons in 1994, 2003, 2006, 2008, 2010 and 2012. The instrument was also compared with the traveling QUASUME (QUality Assurance of Spectral UV Measurements in Europe) unit in 2004 (Gröbner et al., 2004).

\subsection{Global solar radiation}

The global solar radiation is a measure of the rate of total incoming solar energy (both direct and diffuse) on a horizontal plane at the surface of the Earth (Journée and Bertrand, 2010). The measurements at Uccle are performed by CM11 pyranometers (Kipp \& Zonen; http://www.kippzonen.com). For this study, the daily values in $\mathrm{J} \mathrm{m}^{-2}$, derived from 10 and $30 \mathrm{~min}$ data, are used. The data are quality-controlled in two steps: first a preliminary fully automatic quality control is performed prior to the systematic manual check of the data (Journée and Bertrand, 2010). In May 1996 we switched to a new system, and in 2005 half of the instruments were replaced. Corrections to the measurements were made in 2000 , 2001, 2004, 2005, 2007 and 2012. For the period before 1996 , no information is available concerning possible calibrations of the instrument.

\subsection{Total ozone column}

Total ozone column values (in Dobson Units, DU) are available from Brewer\#016 direct sun (DS) measurements. The instrument records raw photon counts of the photomultiplier at five wavelengths $(306.3,310.1,313.5,316.8$ and $320.1 \mathrm{~nm}$ ) using a blocking slit mask, which opens successively one of the five exit slits. The five exit slits are scanned twice within $1.6 \mathrm{~s}$, and this is repeated 20 times. The whole procedure is repeated five times for a total of about $3 \mathrm{~min}$. The total ozone column is obtained from a combination of measurements at $310.1,313.5,316.8$ and $320.1 \mathrm{~nm}$, weighted with a predefined set of constants chosen to minimize the influence of $\mathrm{SO}_{2}$ and linearly varying absorption features from, e.g., clouds or aerosols (Gröbner and Meleti, 2004). Brewer\#016 was calibrated relative to the Dobson instrument in 1984 (De Backer and De Muer, 1991) and regularly recalibrated against the traveling standard Brewer instrument \#017 in 1994, 2003, 2006, 2008, 2010 and 2012. The stability is also continuously checked against the colocated instruments Dobson\#40 (from 1991 until May 2009) and Brewer\#178 (since 2001). Internal lamp tests are performed on a regular basis to check whether the instrument itself is drifting. When instrumental drift is detected, it is corrected for.

\subsection{Aerosol optical depth}

Cheymol and De Backer (2003) developed a method that enables the retrieval of $\tau_{\text {aer }}$ values (at 306.3, 310.1, 313.5, 316.8 and $320.1 \mathrm{~nm}$ ) using the DS measurements of the Brewer instrument. It is also possible to retrieve $\tau_{\text {aer }}$ values at $340 \mathrm{~nm}$ using sun scan (SS) measurements of the Brewer instrument (De Bock et al., 2010). Together with the retrieval method, De Bock et al. (2010) developed a cloud-screening procedure to select the clear-sky $\tau_{\text {aer }}$ values. However, this screening method did not perform well. Hence an improved cloudscreening method (described in Sect. 3.1) has been developed and applied to $\tau_{\text {aer }}$ values retrieved from DS and SS measurements. For this study only the cloud-screened $\tau_{\text {aer }}$ values at $320.1 \mathrm{~nm}$, retrieved from the DS measurements of the single monochromator Brewer\#016, will be used.

\section{Method}

\subsection{Improved aerosol optical depth cloud-screening method}

The initial cloud-screening algorithm, as described in De Bock et al. (2010), did not perform well and improvements 
Table 1. Comparison of Brewer and Cimel aerosol optical depth values (2006-2013).

\begin{tabular}{lcccr}
\hline & & Correlation & Slope & Intercept \\
\hline DS 320 nm & Brewer\#016 & 0.97 & $1.004 \pm 0.006$ & $-0.067 \pm 0.003$ \\
DS 320 nm & Brewer\#178 & 0.99 & $1.007 \pm 0.005$ & $0.017 \pm 0.002$ \\
SS 340 nm & Brewer\#178 & 0.98 & $0.993 \pm 0.007$ & $0.073 \pm 0.002$ \\
\hline
\end{tabular}

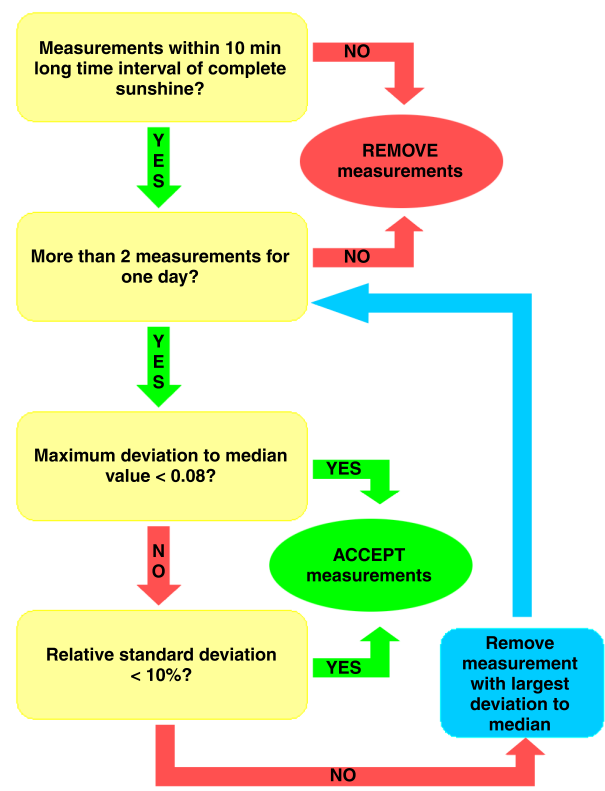

Figure 1. Improved cloud-screening procedure.

were needed. The improved cloud-screening method makes use of sunshine duration data from four pyrheliometers at Uccle and is also based on the assumption that the variability of the $\tau_{\text {aer }}$ in the course of 1 day is either lower than $10 \%$ or lower than $0.08 \tau_{\text {aer }}$ units, which is the maximum uncertainty of the $\tau_{\text {aer }}$ retrieval algorithm. Figure 1 gives a schematic overview of the improved cloud-screening technique. First it is determined whether the individual $\tau_{\text {aer }}$ measurements were taken within a $10 \mathrm{~min}$ interval of continuous sunshine. The measurements for which this is not the case are removed, after which more than two individual measurements per day must remain in order to continue. For each day, we then determine the maximum deviation to the median value. If this value is less than 0.08 , we accept all measurements for that day. However, if the maximum deviation exceeds 0.08 , the relative standard deviation for that day is calculated. In case this value is less than $10 \%$, which would guarantee a given stability within the diurnal pattern of $\tau_{\text {aer }}$, all the $\tau_{\text {aer }}$ values for that day are accepted. In the other case, the $\tau_{\text {aer }}$ measurement with the largest contribution to the standard deviation is removed, as this measurement is most likely influenced by clouds. The median value will then be recomputed and the previous steps are repeated. Days with two or less individual $\tau_{\text {aer }}$ measurements are excluded from the results, since it does not make sense to calculate the deviation to the median and the standard deviation.

The cloud-screened $\tau_{\text {aer }}$, both from DS and SS Brewer measurements, were compared to quasi-simultaneous and colocated Cimel level 2.0 quality-assured values (with a maximum time difference of $3 \mathrm{~min}$ ). The Cimel sun photometer, which belongs to BISA (Belgium Institute of Space Aeronomy), is located approximately $100 \mathrm{~m}$ from the Brewer instrument. It is an automatic sun-sky scanning filter radiometer allowing the measurements of the direct solar irradiance at wavelengths $340,380,440,500,670,870,940$ and $1020 \mathrm{~nm}$. These solar extinction measurements are used to compute aerosol optical depth at each wavelength except for the $940 \mathrm{~nm}$ channel, which is used to retrieve total atmospheric column precipitable water in centimeters. The instrument is part of the AErosol RObotic NETwork (AERONET; http://aeronet.gsfc.nasa.gov/; Holben et al., 2001). The accuracy of the AERONET $\tau_{\text {aer }}$ measurements at $340 \mathrm{~nm}$ is 0.02 (Eck et al., 1999). For the period of comparison (2006-2013), the correlation coefficient, slope and intercept of the regression lines have been calculated, and the values are presented in Table 1. The results of the comparison show that the cloud-screened Brewer $\tau_{\text {aer }}$ values agree very well with the Cimel data.

The advantages of the improved cloud-screening method are the removal of the arbitrary maximum level of $\tau_{\text {aer }}$ values and the fact that it runs completely automatically, whereas the old one needed manual verification afterwards. This method has now been applied not only to the $\tau_{\text {aer }}$ retrieval using SS measurements at $340 \mathrm{~nm}$ but also to the method using DS measurements.

\subsection{Data analysis methods}

Since most statistical analysis tests, such as linear regression and change-point tests, rely on independent and identically distributed time series (e.g., Van Malderen and De Backer, 2010, and references therein), most data used in this study are in their anomaly form. Monthly anomalies are used to reduce the influence of the seasonal cycle on the analysis and are calculated by subtracting the long-term monthly mean from the individual monthly means. Monthly means are only calculated for months with at least 10 individual daily values. For $S_{\text {ery }}, S_{\mathrm{g}}$ and $Q_{\mathrm{O}_{3}}$, accepting monthly means with only 10 daily individual values does not have an impact on the calculated trends, as respectively 85,99 and $100 \%$ of the 
months consist of more than 20 individual daily values. For $\tau_{\text {aer }}$, however, the number of available monthly mean values is dramatically reduced (from 92 to only 5 remaining values) when only accepting monthly means based on 20 individual values. There is a risk in accepting months with only 10 daily values, as those days could be concentrated at the beginning or end of a month, which could bias the calculated trend. However, the benefit of using 92 instead of 5 monthly mean values for $\tau_{\text {aer }}$ trend calculations outweighs this potential bias. For the multiple linear regression analysis, daily values will be used instead of anomaly values.

\subsubsection{Linear trend analysis}

Linear trends are calculated for the monthly anomalies of $S_{\text {ery }}, S_{\mathrm{g}}, Q_{\mathrm{O}_{3}}$ and $\tau_{\text {aer }}$ at $320.1 \mathrm{~nm}$. To determine the significance of the linear trends, the method described in Santer et al. (2000) is used. The least-squares linear regression estimate of the trend in $x(t), b$, minimizes the squared differences between $x(t)$ and the regression line $\hat{x}(t)$ :

$\hat{x}(t)=a+b(t) ; t=1, \ldots, n_{t}$.

Whether a trend in $x(t)$ is significantly different from 0 is tested by computing the ratio between the estimated trend $(b)$ and its standard error $\left(s_{\mathrm{b}}\right)$ :

$t_{\mathrm{b}}=\frac{b}{s_{\mathrm{b}}}$.

Under the assumption that $t_{\mathrm{b}}$ is distributed as Student's $t$, the calculated $t$ ratio is then compared with a critical $t$ value, $t_{\text {crit }}$, for a stipulated significance level $\alpha$ and $n_{t}-2$ degrees of freedom (Santer et al., 2000).

However, if the regression residuals are autocorrelated, the results of the regression analysis will be too liberal and the original approach must be modified. The method proposed in Santer et al. (2000) involves the use of an effective sample size $n_{\mathrm{e}}$ in the computation of the adjusted standard error and calculated $t$ value, but also in the indexing of the critical $t$ value. To test for autocorrelation in the residuals of a time series, the Durbin-Watson test is used (Durbin and Watson, 1971).

The above-described linear trend analysis is also applied to the monthly anomalies of the extreme values (minima and maxima) of the variables. The extreme values are calculated by determining the lowest and highest measured value for each month. These trends will be studied together with the relative frequency distribution of the daily mean values. This distribution is determined by using the minimum and maximum values of the entire study period as boundaries and by dividing the range between the boundaries into a certain amount of bins of equal size. The daily values are distributed over the different bins, and the relative frequency in percent is calculated. This will be done for two different time periods: 1991-2002 and 2003-2013. Additionally, the medians for these periods are calculated. In this way, it is possible to investigate whether there is a shift in the frequency distribution of the variables from the first period to the second one. The results of the analysis of the frequency distribution will only be presented in case they show a significant shift in the data.

\subsubsection{Change-point analysis}

Change points are times of discontinuity in a time series (Reeves et al., 2007) and can either arise naturally or as a result of errors or changes in instrumentation, recording practices, data transmission, processing, etc. (Lanzante, 1996). A change point is said to occur at some point in the sequence if all the values up to and including it share a common statistical distribution and all those after the point share another. The most common change-point problem involves a change in the mean of the time series (Lanzante, 1996). There are different tests that can be used to detect a change point in a time series. In this study we use the combination of three tests: the non-parametric Pettitt-Mann-Whitney (PMW) test (based on the ranks of the values in the sequence), the Mann-Whitney-Wilcoxon (MWW) test (a rank sum test) and the cumulative sum technique (CST). The details of these tests are described in Hoppy and Kiely (1999). The change points discussed further in this study are detected by all three tests (except when mentioned otherwise), and only the change points that exceeded the $90 \%$ confidence level were retained. The change points are determined for the monthly anomalies time series of $S_{\text {ery }}, S_{\mathrm{g}}, Q_{\mathrm{O}_{3}}$ and $\tau_{\text {aer }}$ at $320.1 \mathrm{~nm}$. When there is a clear and large-enough, statistically significant trend present in the time series, this automatically leads to the detection of a change point in the middle of the time series as, at this point, the change in the mean is large enough to be significant. In this case, it is necessary to detrend the time series, i.e., subtract the general trend from the time series.

\subsubsection{Multiple linear regression analysis}

The goal of a MLR analysis is to determine the values of parameters for a linear function that cause this function to best describe a set of provided observations (Krishna Prasad et al., 2011). In this study, the MLR technique is used to explore whether there is a significant relationship between $S_{\text {ery }}$ and three explanatory variables $\left(S_{\mathrm{g}}, Q_{\mathrm{O}_{3}}\right.$ and $\left.\tau_{\text {aer }}\right)$ both on a daily and seasonal scale. We use a linear model where the coefficients are determined with the least-squares method:

$S_{\text {ery }}=a \times S_{\mathrm{g}}+b \times Q_{\mathrm{O}_{3}}+c \times \tau_{\mathrm{aer}}+d+\epsilon$

with

- $S_{\text {ery }}$ : erythemal UV dose (in $\mathrm{J} \mathrm{m}^{-2}$ )

- $S_{\mathrm{g}}$ : global solar radiation (in $\mathrm{J} \mathrm{m}^{-2}$ ) 
- $Q_{\mathrm{O}_{3}}$ : total ozone column (in DU)

- $\tau_{\text {aer }}$ aerosol optical depth at $320.1 \mathrm{~nm}$

- $a, b, c$ : regression coefficients

- $d$ : constant term

- $\epsilon$ : error term.

Although the attenuation of radiation by ozone is not linear (according to the Beer-Lambert law), we consider total ozone column as a linear independent variable, based on the limited variation of this variable throughout the year and throughout the different seasons.

The model will be developed based on data from 1991 to 2008. Data from 2009 to 2013 will be used for validation of the model. For the MLR analysis to produce trustworthy results, the distribution of the errors of the model should be normal. Non-normal errors may mean that the $t$ and $F$ statistics of the coefficients may not actually follow $t$ and $F$ distributions and that the model might underestimate reality (Williams et al., 2013). However, as stated in Williams et al. (2013), even if errors are not normally distributed, the sampling distribution of the coefficients will approach a normal distribution as sample size grows larger, assuming some reasonably minimal precondititions. As we have a large data set available at Uccle for the MLR analysis, we can assume that the distribution of the coefficients of the MLR model approaches normality.

The performance of the model and its parameters will be evaluated through different statistical parameters. The adjusted $R^{2}$ value is the measure for the fraction of variation in UV explained by the regression, accounting for both the sample size and the number of explanatory variables. Compared to the $R^{2}$ value, the adjusted $R^{2}$ value will only increase if a new variable has additional explanatory power. It is possible to test the null hypothesis that a regression coefficient is equal to 0 , which would mean that the variable associated with this regression coefficient does not contribute to explaining the variation in UV. This is done by looking at the $p$ value. If we want to test whether a regression coefficient differs significantly from 0 at the $5 \%$ level, the $p$ value should be less than or equal to 0.05 . The influence of the variation in the three parameters on the variation of $S_{\text {ery }}$ is determined by multiplying the standard deviation of each parameter with its corresponding regression coefficient and dividing this by the average $S_{\text {ery }}$ value.

The mean bias error (MBE) and the mean absolute bias error (MABE) are also calculated in order to evaluate the performance of the regression model. The MBE (given in \%) provides the mean relative difference between modeled and measured values (Antón et al., 2009):
Table 2. Seasonal trends of erythemal UV doses (1991-2013).

\begin{tabular}{lcc}
\hline Season & Trend per decade & Significance level \\
\hline Spring & $+9 \%( \pm 3 \%)$ & $99 \%$ \\
Summer & $+6 \%( \pm 2 \%)$ & $99 \%$ \\
Autumn & $+7 \%( \pm 3 \%)$ & $95 \%$ \\
Winter & $-12 \%( \pm 4 \%)$ & $99 \%$ \\
\hline
\end{tabular}

MBE $=100 \times \frac{1}{N} \sum_{i=1}^{N} \frac{S_{\text {ery }_{i}}^{\text {modeled }}-S_{\text {ery }_{i}}^{\text {measured }}}{S_{\text {ery }_{i}}^{\text {meared }}}$.

The MABE (given in \%) reports on the absolute value of the individual differences between modeled and measured data (Antón et al., 2009):

MABE $=100 \times \frac{1}{N} \sum_{i=1}^{N} \frac{\left|S_{\text {ery }_{i}}^{\text {moled }}-S_{\text {ery }_{i}}^{\text {measured }}\right|}{S_{\text {ery }_{i}}^{\text {meared }}}$.

\section{Results and discussion}

\subsection{Linear trend analysis}

\subsubsection{Erythemal UV dose}

A significant positive trend (at the $99 \%$ significance level) can be detected in the time series of monthly anomalies of $S_{\text {ery }}$ (Fig. 2). These values increase by $7 \%( \pm 2 \%)$ per decade. The seasonal trends are presented in Table 2. In spring (March, April and May), summer (June, July and August) and autumn (September, October and November), $S_{\text {ery }}$ increases significantly, whereas in winter (December, January and February) the trend is negative. The increase in $S_{\text {ery }}$ is the largest in spring.

A significant positive trend has been found in the monthly anomalies of both the minimum and maximum values of $S_{\text {ery }}$. The minimum values show an increase of $10 \%( \pm 4 \%)$ per decade and the maximum values increased by $7 \%( \pm 1 \%)$ per decade (respectively at the 95 and $99 \%$ level). The increase in the median value from $825 \mathrm{~J} \mathrm{~m}^{-2}(1991-2002)$ to $987 \mathrm{~J} \mathrm{~m}^{-2}$ (2003-2013) shows that higher $S_{\text {ery }}$ values are more frequent in the latter period.

\subsubsection{Global solar radiation}

The values of $S_{\mathrm{g}}$ show an increase of $4 \%( \pm 1 \%)$ per decade at the $99 \%$ significance level, which corresponds to an absolute change of $+0.5( \pm 0.2) \mathrm{W} \mathrm{m}^{-2}$ per year for the observed time period (Fig. 2). On a seasonal scale, spring and autumn exhibit a significant positive trend (Table 3 ). The seasonal trends of $S_{\mathrm{g}}$, although not significant in summer and winter, 

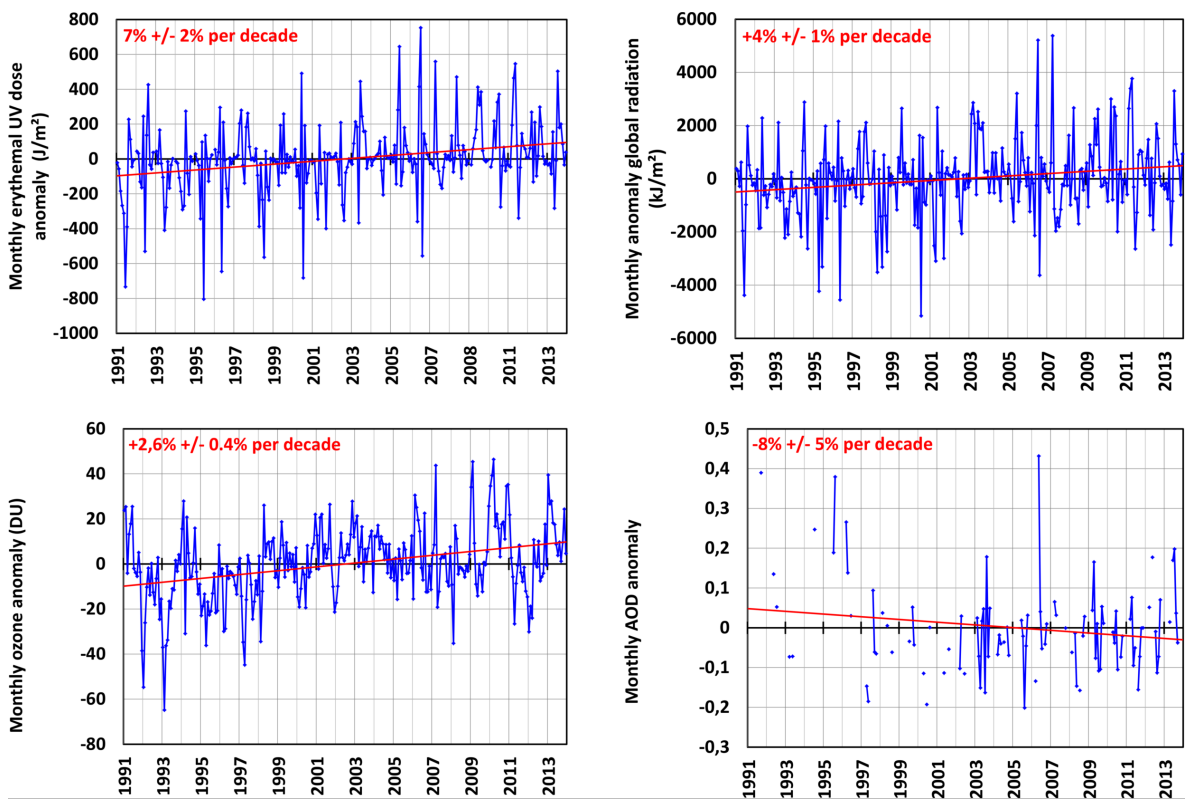

Figure 2. Trends of monthly anomalies at Uccle for erythemal UV dose (upper left panel), global solar radiation (upper right panel), total ozone column (lower left panel) and aerosol optical depth at $320.1 \mathrm{~nm}$ (lower right panel) for the time period 1991-2013. The blue lines represent the time series, whereas the red lines represent the trend over the time period.

Table 3. Seasonal trends of global solar radiation (1991-2013).

\begin{tabular}{lcc}
\hline Season & Trend per decade & Significance level \\
\hline Spring & $+6 \%( \pm 3 \%)$ & $95 \%$ \\
Summer & $+2 \%( \pm 2 \%)$ & not significant \\
Autumn & $+6 \%( \pm 3 \%)$ & $95 \%$ \\
Winter & $-4 \%( \pm 4 \%)$ & not significant \\
\hline
\end{tabular}

have the same sign as the seasonal $S_{\text {ery }}$ trends. The trends of $S_{\mathrm{g}}$ are smaller than the $S_{\text {ery }}$ trends, both on an annual and seasonal scale.

There is a clear difference between the trends of the monthly anomalies of minimum and maximum values of $S_{\mathrm{g}}$. Both trends are positive, but the increase in the minimum values $(12 \%( \pm 5 \%)$ per decade at $99 \%$ significance level) is much larger than the one in the maximum values $(3.2 \%$ $( \pm 0.7 \%)$ per decade at $99 \%$ significance level). Study of the median values reveals the presence of an increase from $7880 \mathrm{~kJ} \mathrm{~m}^{-2}$ (1991-2002) to $8902 \mathrm{~kJ} \mathrm{~m}^{-2}$ (2003-2013). As the global radiation data are all-sky data, it is obvious that the minimum values are the ones that are influenced by clouds. If the minimum values increase in time, the cloud properties, i.e., their amount and/or water content, must have changed over the past 23 years.

\subsubsection{Total ozone column}

The monthly anomalies of $Q_{\mathrm{O}_{3}}$ show a positive trend of $2.6 \%( \pm 0.4 \%)$ per decade (significant at $99 \%$ ) (Fig. 2). Sig-
Table 4. Seasonal trends of total ozone column (1991-2013).

\begin{tabular}{lcc}
\hline Season & Trend per decade & Significance level \\
\hline Spring & $+3 \%( \pm 1 \%)$ & $95 \%$ \\
Summer & $+1.6 \%( \pm 0.6 \%)$ & $95 \%$ \\
Autumn & $+1.8 \%( \pm 0.9 \%)$ & not significant \\
Winter & $+3 \%( \pm 2 \%)$ & not significant \\
\hline
\end{tabular}

Table 5. Seasonal trends of aerosol optical depth at $320.1 \mathrm{~nm}$ (1991-2013).

\begin{tabular}{lcc}
\hline Season & Trend per decade & Significance level \\
\hline Spring & $+2 \%( \pm 7 \%)$ & not significant \\
Summer & $-18 \%( \pm 8 \%)$ & $95 \%$ \\
Autumn & $-36 \%( \pm 14 \%)$ & $95 \%$ \\
Winter & not enough data & \\
\hline
\end{tabular}

nificant positive trends occur in spring and summer (Table 4), with the trend in spring being the largest one. As opposed to the seasonal trends of $S_{\text {ery }}$ and $S_{\mathrm{g}}$, the ones for $Q_{\mathrm{O}_{3}}$ are positive for each season. We would expect an increase in $Q_{\mathrm{O}_{3}}$ over the past 23 years to be accompanied by a decrease in $S_{\text {ery }}$, which is not the case for the Uccle time series. This indicates that other variables might contribute to the change in $S_{\text {ery }}$ and that the contribution of $Q_{\mathrm{O}_{3}}$ might be washed out by the influence of these other variables.

Both the minimum and maximum $Q_{\mathrm{O}_{3}}$ values increased significantly $(99 \%$ level) at the same rate: $3.0 \%( \pm 0.6 \%)$ 


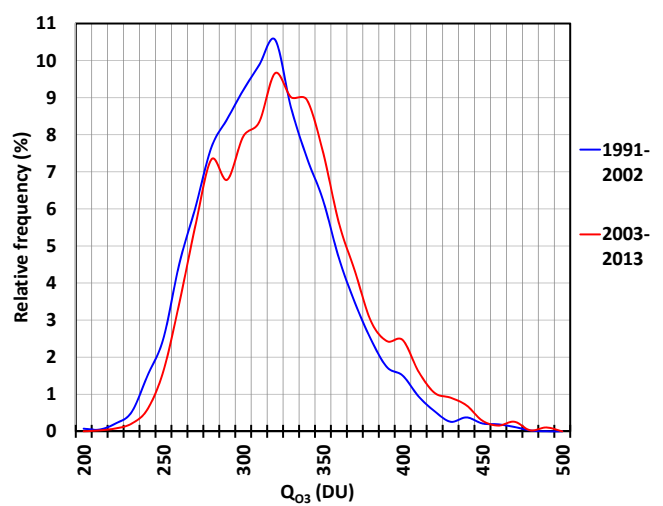

Figure 3. Relative frequency distribution of daily total ozone column values for the two time periods: 1991-2002 (in blue) and 2003-2013 (in red).

per decade for the minimum values and $3.1 \%( \pm 0.6 \%)$ per decade for the maximum values over the past 23 years. A clear shift can be seen in the frequency distribution (Fig. 3) of the daily $Q_{\mathrm{O}_{3}}$ values. During the second period (2003-2013), higher values are more frequent than during the previous period (1991-2002), which is supported by the increase in median values from 319.3 DU (199-2002) to $327.9 \mathrm{DU}$ (2003-2013). The entire curve of the frequency distribution is shifted, which means that the minimum values of the distribution have also increased between the two decades. After a period with lower $Q_{\mathrm{O}_{3}}$ values in the $1990 \mathrm{~s}$, it seems that ozone has been recovering over the past 10 years. Removing the Pinatubo period (1991-1993) from our analysis does not change the trend in ozone significantly, which means that the observed recovery in ozone is not very much related to the return of the stratosphere to pre-Pinatubo time but rather that it is more likely a result of the regulations of the Montreal Protocol.

\subsubsection{Aerosol optical depth at $320.1 \mathrm{~nm}$}

While the overall trends of $S_{\text {ery }}, S_{\mathrm{g}}$ and $Q_{\mathrm{O}_{3}}$ are all positive, the $\tau_{\text {aer }}$ values at $320.1 \mathrm{~nm}$ show a negative trend of $-8 \%$ $( \pm 5 \%)$ per decade. This trend, however, is not significant (Fig. 2). The seasonal trends (Table 5) show that the summer and autumn trends are significantly negative, with the largest trend being observed during autumn. Due to a lack of sufficient clear-sky data, it was not possible to determine the winter trend for $\tau_{\text {aer }}$.

There are no significant changes in the minimum and maximum $\tau_{\text {aer }}$ values over the 1991-2013 period. From the relative frequency distribution of the daily $\tau_{\text {aer }}$ values (Fig. 4 ), it can be seen that the frequency of lower $\tau_{\text {aer }}$ values $\left(\tau_{\text {aer }}<0.4\right)$ was higher during the second period (2003-2013). The frequency of high $\tau_{\text {aer }}$ values ( $\tau_{\text {aer }}>0.7$ ) has also decreased towards the second decade. This is in agreement with the overall decrease in $\tau_{\text {aer }}$ over the last 23 years. However, this is

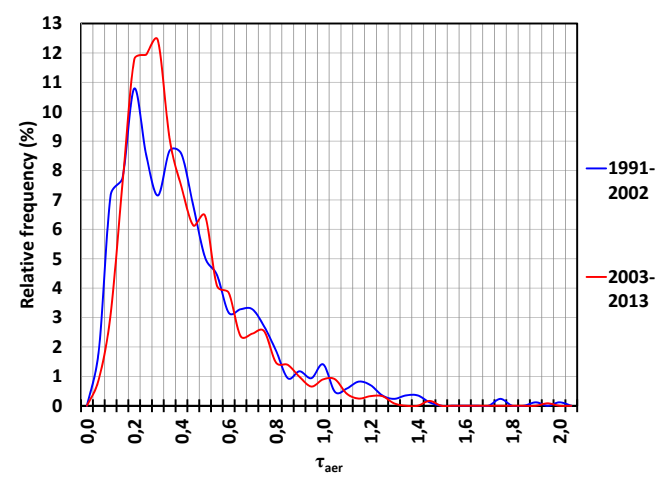

Figure 4. Relative frequency distribution of daily aerosol optical depth values for the two time periods: 1991-2002 (in blue) and 2003-2013 (in red).

not obvious from the median values as they decreased only slightly from 0.38 (1991-2002) to 0.36 (2003-2013).

\subsection{Comparison of Uccle trends with other stations}

\subsubsection{Erythemal UV dose}

Long-term UV trends for different locations around the world have been the subject of many research articles (e.g., den Outer et al., 2000; Zerefos et al., 2012; Eleftheratos et al., 2014), and it is worth checking the consistency of our results with these studies even though the time periods are never exactly the same as the one studied in this paper (1991-2013). Some trends (observed or modeled/reconstructed) found in the literature are presented in Table 6. Looking at these trends, it can be seen that for the stations with comparable latitude to Uccle $\left(45-55^{\circ} \mathrm{N}\right)$, the trends in UV range from -2.1 to $+14.2 \%$ per decade. The increase of $7 \%( \pm 2 \%)$ per decade observed at Uccle falls within the range of trends reported in the literature. However, for the comparison of these trends, it has to be taken into account that not all trends in Table 6 are calculated in the same say as the one at Uccle. At Uccle, trends are based on monthly anomalies which are essentially calculated from daily doses. As such, all effects such as those from clouds are included in our analysis. Some of the studies from Table 6 report trends at a certain fixed solar zenith angle, which does not cover the same range of effects as the daily sum does, and thus the trends may not be truly comparable. The possible effect of a different concept of UV could be the subject of a later study. On a more global scale, Zerefos et al. (2012) examined UV irradiance over selected sites in Canada, Europe and Japan between 1990 and 2011. The results, based on observations and modeling for all stations, showed an increase in UV irradiances of $3.7 \%( \pm 0.5 \%)$ and $5.5 \%( \pm 0.3 \%)$ per decade at respectively 305 and $325 \mathrm{~nm}$. For Europe, only the trend at $325 \mathrm{~nm}$ (3.4\% ( $\pm 0.4 \%)$ per decade) was significant. The COST 726 action (Litynska et al., 2009; www.cost726.org) calculated 
Table 6. Trends of UV radiation at different stations from (a) Bais et al. (2007), (b) Krzýscin et al. (2011), (c) Smedley et al. (2012), (d) Fitzka et al. (2012), (e) den Outer et al. (2010) and (f) Chubarova (2008).

\begin{tabular}{lllll}
\hline Station, country & Latitude/longitude & Period & Trend/decade & Reference \\
\hline Measured UV trends & & & & \\
\hline Sodankylä, Finland & $67.42^{\circ} \mathrm{N} / 26.59^{\circ} \mathrm{E}$ & $1990-2004$ & $+2.1 \%\left(60^{\circ} \mathrm{SZA}\right)$ & (a) \\
Jokioinen, Finland & $60.80^{\circ} \mathrm{N} / 23.49^{\circ} \mathrm{E}$ & $1996-2005$ & $-1.9 \%\left(60^{\circ} \mathrm{SZA}\right)$ & (a) \\
Norrköping, Sweden & $58.36^{\circ} \mathrm{N} / 16.12^{\circ} \mathrm{E}$ & $1996-2004$ & $+12 \%\left(60^{\circ} \mathrm{SZA}\right)$ & (a) \\
Bilthoven, the Netherlands & $52.13^{\circ} \mathrm{N} / 5.20^{\circ} \mathrm{E}$ & $1996-2004$ & $+8.6 \%\left(60^{\circ} \mathrm{SZA}\right)$ & (a) \\
Belsk, Poland & $51.83^{\circ} \mathrm{N} / 20.81^{\circ} \mathrm{E}$ & $1976-2008$ & $+5.6 \%$ & (b) \\
Reading, United Kingdom & $51.45^{\circ} \mathrm{N} / 0.98^{\circ} \mathrm{W}$ & $1993-2008$ & $+6.6 \%$ & (c) \\
Hradec Kralove, Czech Rep. & $50.21^{\circ} \mathrm{N} / 15.82^{\circ} \mathrm{E}$ & $1994-2005$ & $-2.1 \%\left(60^{\circ} \mathrm{SZA}\right)$ & (a) \\
Lindenberg, Germany & $47.60^{\circ} \mathrm{N} / 9.89^{\circ} \mathrm{E}$ & $1996-2003$ & $+7.7 \%\left(60^{\circ} \mathrm{SZA}\right)$ & (a) \\
Hoher Sonnblick, Austria & $47.05^{\circ} \mathrm{N} / 12.96^{\circ} \mathrm{E}$ & $1997-2011$ & $+14.2 \%\left(65^{\circ} \mathrm{SZA}\right)$ & (d) \\
Thessaloniki, Greece & $40.63^{\circ} \mathrm{N} / 22.95^{\circ} \mathrm{E}$ & $1990-2004$ & $+3.4 \%\left(60^{\circ} \mathrm{SZA}\right)$ & (a) \\
\hline Reconstructed or & & & & \\
Modeled UV trends & & & & (e) \\
\hline Sodankylä, Finland & $67.42^{\circ} \mathrm{N} / 26.59^{\circ} \mathrm{E}$ & $1980-2006$ & $+3.6 \%$ & (e) \\
Jokioinen, Finland & $60.80^{\circ} \mathrm{N} / 23.49^{\circ} \mathrm{E}$ & $1980-2006$ & $+2.8 \%$ & (e) \\
Norrköping, Sweden & $58.36^{\circ} \mathrm{N} / 16.12^{\circ} \mathrm{E}$ & $1980-2006$ & $+4.1 \%$ & (f) \\
Moscow, Russia & $55.75^{\circ} \mathrm{N} / 37.62^{\circ} \mathrm{E}$ & $1980-2006$ & $+6 \%$ & (e) \\
Bilthoven, the Netherlands & $52.13^{\circ} \mathrm{N} / 5.20^{\circ} \mathrm{E}$ & $1980-2006$ & $+2.9 \%$ & (e) \\
Hradec Kralove, Czech Rep. & $50.21^{\circ} \mathrm{N} / 15.82^{\circ} \mathrm{E}$ & $1980-2006$ & $+5.2 \%$ & (e) \\
Lindenberg, Germany & $47.60^{\circ} \mathrm{N} / 9.89^{\circ} \mathrm{E}$ & $1980-2006$ & $+5.8 \%$ & (e) \\
Thessaloniki, Greece & $40.63^{\circ} \mathrm{N} / 22.95^{\circ} \mathrm{E}$ & $1980-2006$ & $+4.4 \%$ & \\
\hline
\end{tabular}

trend values for European sites and saw a mean positive trend of $4.5 \%( \pm 0.5 \%)$ per decade since 1980 , which was derived from reconstruction models, based on $Q_{\mathrm{O}_{3}}$ and measured total solar irradiance.

\subsubsection{Global solar radiation}

Concerning the global solar radiation, many publications agree on the existence of a solar dimming period between 1970 and 1985 and a subsequent solar brightening period (Norris and Wild, 2007; Solomon et al., 2007; Makowski et al., 2009; Stjern et al., 2009; Wild et al., 2009; Sanchez-Lorenzo and Wild, 2012). Different studies have calculated the trend in $S_{\mathrm{g}}$ after 1985. The trend in $S_{\mathrm{g}}$ from GEBA (Global Energy Balance Archive; http://www.iac.ethz.ch/groups/schaer/research/rad_ and_hydro_cycle_global/geba) between 1987 and 2002 is equal to $+1.4( \pm 3.4) \mathrm{W} \mathrm{m}^{-2}$ per decade according to Norris and Wild (2007). Stjern et al. (2009) found a total change in the mean surface solar radiation trend over 11 stations in northern Europe of $+4.4 \%$ between 1983 and 2003. In the Fourth Assessment Report of the IPCC (Solomon et al., 2007), 421 sites were analyzed; between 1992 and 2002, the change of all-sky surface solar radiation was equal to $0.66 \mathrm{~W} \mathrm{~m}^{-2}$ per year. Wild et al. (2009) investigated the global solar radiation from 133 stations from GEBA/World Radiation Data Centre belonging to different regions in Europe. All series showed an increase over the entire pe- riod, with a pronounced upward tendency since 2000. For the Benelux region, the linear change between 1985 and 2005 is equal to $+0.42 \mathrm{~W} \mathrm{~m}^{-2}$ per year, compared to the pan-European average trend of $+0.33 \mathrm{~W} \mathrm{~m}^{-2}$ per year (or $+0.24 \mathrm{~W} \mathrm{~m}^{-2}$ if the anomaly of the 2003 heat wave is excluded) (Wild et al. 2009). Our trend at Uccle of +0.5 $( \pm 0.2) \mathrm{W} \mathrm{m}^{-2}$ per year (or $+4 \%$ per decade) agrees within the error bars with the results from Wild et al. (2009), but seems to be somewhat at the high end range.

\subsubsection{Total ozone column}

Ozone and its trends have been the subject of scientific research since the discovery of ozone depletion. Many studies agree that ozone has decreased since 1980 to the mid-1990s as a consequence of anthropogenic emissions of ozone depleting substances. This period of decrease is followed by a period of significant increase (Steinbrecht et al., 2006; Harris et al., 2008; Vigouroux et al., 2008; Krzýscin and Borkowski, 2008; Herman, 2010; Bais et al., 2011). For the period before the mid-1990s, studies report on decreasing ozone values at Brussels (Bojkov et al., 1995 and Zerefos et al., 1997), Reading (Bartlett and Webb, 2000), Lerwick (Smedley et al., 2012), Arosa (Bojkov et al., 1995 and Staehelin et al., 1998), Hohenpeissenberg (Bojkov et al., 1995), Sodankylä (Glandorf et al., 2005) and Thessaloniki (Glandorf et al., 2005) (see Table 7). After the mid-1990s, most studies report on a plateau or a limited increase in ozone. For example, Smedley 
Table 7. Trends of total ozone column at different stations from (a) Glandorf et al. (2005), (b) Smedley et al. (2012), (c) Bartlett and Webb (2000), (d) Bojkov et al. (1995), (e) Zerefos et al. (1997), (f) Fitzka et al. (2012), (g) Staehelin et al. (1998) and (h) Vigouroux et al. (2008).

\begin{tabular}{lllll}
\hline Station, country & Latitude/longitude & Period & Trend/decade & Reference \\
\hline Sodankylä, Finland & $67.42^{\circ} \mathrm{N} / 26.59^{\circ} \mathrm{E}$ & $1979-1998$ & $-5.7 \%$ & (a) \\
Lerwick, United Kingdom & $60.15^{\circ} \mathrm{N} / 1.15^{\circ} \mathrm{W}$ & $1979-1993$ & $-5.8 \%$ & (b) \\
Reading, United Kingdom & $51.45^{\circ} \mathrm{N} / 0.98^{\circ} \mathrm{W}$ & $1993-1997$ & $-5.9 \%$ & (c) \\
Brussels, Belgium & $50.84^{\circ} \mathrm{N} / 4.36^{\circ} \mathrm{E}$ & $1971-1994$ & $-2.6 \%$ & (d) \\
Brussels, Belgium & $\mathrm{idem}$ & $1993-1996$ & $-15.0 \%$ & $(\mathrm{e})$ \\
Hradec Kralove, Czech Rep. & $50.21^{\circ} \mathrm{N} / 15.82^{\circ} \mathrm{E}$ & $1994-2005$ & $-2.2 \%$ & (d) \\
Hohenpeisenberg, Germany & $47.80^{\circ} \mathrm{N} / 11.00^{\circ} \mathrm{E}$ & $1968-1994$ & $-3.5 \%$ & (d) \\
Hoher Sonnblick, Austria & $47.05^{\circ} \mathrm{N} / 12.96^{\circ} \mathrm{E}$ & $1997-2011$ & $+1.9 \%$ & (f) \\
Arosa, Switzerland & $46.77^{\circ} \mathrm{N} / 9.67^{\circ} \mathrm{E}$ & $1964-1994$ & $-2.7 \%$ & (d) \\
Arosa, Switzerland & $\mathrm{idem}$ & $1970-1996$ & $-2.3 \%$ & (g) \\
Jungfraujoch, Switzerland & $46.55^{\circ} \mathrm{N} / 7.98^{\circ} \mathrm{E}$ & $1995-2004$ & $+4.1 \%$ & (h) \\
Thessaloniki, Greece & $40.63^{\circ} \mathrm{N} / 22.95^{\circ} \mathrm{E}$ & $1993-1996$ & $-4.0 \%$ & (e) \\
Thessaloniki, Greece & $\mathrm{idem}$ & $1990-1998$ & $-4.5 \%$ & (a) \\
\hline
\end{tabular}

et al. (2012) found no clear ozone trend in the 1993-2008 period for Reading. Ozone observations from a Brewer instrument at Hoher Sonnblick (Fitzka et al., 2012) showed a small but significant increase between 1997 and 2011. Similar behavior was reported for Jungfraujoch in Vigouroux et al. (2008). Our result, a trend of $+2.6 \%$ per decade, compares well with the trend observed at Hoher Sonnblick, which is the only station with a time period comparable to the one at Uccle. From Figs. 2 and 6, it can be seen that a negative trend occurred in the $Q_{\mathrm{O}_{3}}$ values before 1998 and that this trend was followed by a positive one. However, neither trend is significant at Uccle. It is difficult to unambiguously attribute the ozone trends to changes in ODSs because other factors also contribute to ozone variability and trends. These factors are large volcanic eruptions, Arctic ozone depletion, long-term climate variability, changes in the stratospheric circulation and the 11-year solar cycle (Harris et al., 2008; Vigouroux et al., 2008). According to Rieder et al. (2013), the equivalent effective stratospheric chlorine and the 11-year solar cycle can be identified as major contributors, but the influence of dynamical features (such as the El Niño-Southern Oscillation, North Atlantic Oscillation and Quasi-Biennial Oscillation) on the ozone variability and trends can not be neglected at a regional level.

\subsubsection{Aerosol optical depth at $320.1 \mathrm{~nm}$}

Trend analysis studies of long time series of aerosol optical depth are still very scarce at the moment. Some studies, however, do report on aerosol trends (Table 8). Mishchenko and Geogdzhayev (2007) observed a significant decrease in $\tau_{\mathrm{aer}}$ from 1991 to 2005 over much of Europe within the GACP (Global Aerosol Climatology Project; http://gacp.giss.nasa. gov/) data. Alpert et al. (2012) studied $\tau_{\text {aer }}$ trends from MODIS (MODerate-resolution Imaging Spectroradiometer) and MISR (Multi-angle Imaging SpectroRadiometer) satel- lite measurements over the 189 largest cities in the world and saw a decrease in $\tau_{\text {aer }}$ over Europe for the 2002-2010 period. The decadal trend observed by de Meij et al. (2012) over Europe between 2000 and 2009 was negative for MODIS $(-30 \%)$, MISR $(-9 \%)$ and AERONET $(-25 \%)$. Zerefos et al. (2012) - who investigated the $\tau_{\text {aer }}$ over Europe, Japan and Canada - discovered a general decline in $\tau_{\text {aer }}$ exceeding $10 \%$ per year. For Europe specifically, the trend of $\tau_{\text {aer }}$ varied between $-16.6 \%( \pm 6 \%)$ per decade when using the GACP data set and $-42.8 \%( \pm 5.7 \%)$ for the MODIS data set. The insignificant trend of $-8 \% \pm 5 \%$ per decade observed at Uccle lies within the range of trends observed at other European stations. The long-term $\tau_{\text {aer }}$ decrease over much of Europe is quite consistent with the supposed reversal from increasing to decreasing anthropogenic sulfur and black carbon emissions owing to the enactment of clean-air legislation in many countries (Mishchenko and Geogdzhayev, 2007; Chiaccio et al., 2011; Alpert et al., 2012; de Meij et al., 2012; Hsu et al., 2012; Nabat et al., 2013). This change occurred after 1988-1989, the time period when a maximum was reached in the emissions of sulfate aerosols over Europe (Chiaccio et al., 2011). Many scientists believe that the decadal changes in aerosols have influenced the amount of solar radiation reaching the surface of the Earth and that the decrease in aerosols has played a part in the switch from global dimming to global brightening, which occurred around 1980-1990 (Augustine et al., 2008; Chiaccio et al., 2011). According to Wild et al. (2009), the reduction of aerosols may have played a role during the 1990s but not after 2000. Decreases in cloudiness or cloud albedo may have enabled the continuation of the increase in surface solar radiation over Europe beyond 2000, despite the stabilization of aerosol concentrations. 
Table 8. Absolute and relative trends of aerosol optical depth at different stations from (a) Alpert et al. (2012), (b) Nyeki et al. (2012), (c) Fitzka et al. (2012) and (d) Kazadzis et al. (2007). MODIS-Terra, MODIS-Aqua and MISR measurements are represented by respectively "a", "b" and "c" after the station name.

\begin{tabular}{lllll}
\hline Station, country & Latitude/longitude & Period & Trend/decade & Reference \\
\hline Berlin (a), Germany & $52.50^{\circ} \mathrm{N} / 13.40^{\circ} \mathrm{E}$ & $2002-2010$ & $-20.5 \%$ & (a) \\
Berlin (b), Germany & idem & $2002-2010$ & $-17.9 \%$ & (a) \\
Berlin (c), Germany & idem & $2002-2010$ & $-12.3 \%$ & (a) \\
Warsaw (a), Poland & $52.30^{\circ} \mathrm{N} / 21.00^{\circ} \mathrm{E}$ & $2002-2010$ & $-2.4 \%$ & (a) \\
Warsaw (b), Poland & idem & $2002-2010$ & $-0.4 \%$ & (a) \\
Warsaw (c), Poland & idem & $2002-2010$ & $+12.9 \%$ & (a) \\
Ruhr Area (a), Germany & $51.50^{\circ} \mathrm{N} / 7.50^{\circ} \mathrm{E}$ & $2002-2010$ & $-15.7 \%$ & (a) \\
Ruhr Area (b), Germany & idem & $2002-2010$ & $-9.3 \%$ & (a) \\
Ruhr Area (c), Germany & idem & $2002-2010$ & $-9.3 \%$ & (a) \\
Paris (a), France & $48.90^{\circ} \mathrm{N} / 2.40^{\circ} \mathrm{E}$ & $2002-2010$ & $-8.1 \%$ & (a) \\
Paris (b), France & idem & $2002-2010$ & $+5.0 \%$ & (a) \\
Paris (c), France & idem & $2002-2010$ & $+9.8 \%$ & (a) \\
Hohenpeisenberg, Germany & $47.80^{\circ} \mathrm{N} / 11.00^{\circ} \mathrm{E}$ & $1995-2010$ & $-10.6 \%$ & (b) \\
Hoher Sonnblick, Austria & $47.05^{\circ} \mathrm{N} / 12.96^{\circ} \mathrm{E}$ & $1997-2011$ & -5 to -6\% & (c) \\
Barcelona (a), Spain & $41.40^{\circ} \mathrm{N} / 2.20^{\circ} \mathrm{E}$ & $2002-2010$ & $-8.8 \%$ & (a) \\
Barcelona (b), Spain & idem & $2002-2010$ & $+4.2 \%$ & (a) \\
Barcelona (c), Spain & idem & $2002-2010$ & $-2.3 \%$ & (a) \\
Thessaloniki, Greece & $40.63^{\circ} \mathrm{N} / 22.95^{\circ} \mathrm{E}$ & $1997-2006$ & $-29.0 \%$ & (d) \\
Madrid (a), Spain & $40.40^{\circ} \mathrm{N} / 3.70^{\circ} \mathrm{W}$ & $2002-2010$ & $-18.3 \%$ & (a) \\
Madrid (b), Spain & idem & $2002-2010$ & $-10.0 \%$ & (a) \\
Madrid (c), Spain & idem & $2002-2010$ & $-7.4 \%$ & (a) \\
\hline
\end{tabular}

\subsection{Change-point analysis}

\subsubsection{Erythemal UV dose}

According to the three tests (PMW, MWW and CST) of the change-point analysis, there is a significant shift in the mean of the monthly anomalies of $S_{\text {ery }}$ around January 2003. The change point is located suspiciously close to the middle of the time series, however. To remove the influence of the presence of one general increasing trend, which would lead to the discovery of a change point in the middle of the time series, the time series was detrended. This is done by subtracting the general trend from the original time series. The change point in the detrended time series is located around February 1998 (Fig. 5). Since there was no change in the calibration constants of the Brewer instrument around that period, it seems that the change point is not caused by known instrumental changes but rather by natural/environmental changes.

\subsubsection{Global solar radiation}

A significant change point was detected (only by the PMW test) around January 2003 in the time series of $S_{\mathrm{g}}$. Similar to the $S_{\text {ery }}$ time series, there is one general positive trend present, which explains the detection of a change point near the middle of the time series. Thus, it was again decided to look at the detrended time series of $S_{\mathrm{g}}$. However, the detected change point around January 2006 (only by the PMW test) was not significant at the $90 \%$ significance level.

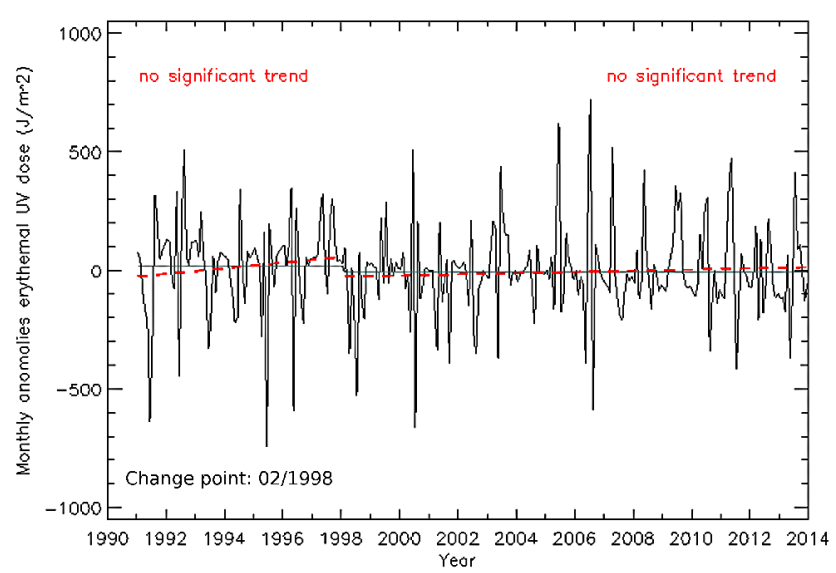

Figure 5. The black line represents the detrended time series of monthly anomalies of erythemal UV dose (1991-2013). The red (dashed) lines represent the (insignificant) positive trends before and after the detected change point. The grey lines represent the mean before and after the change point.

\subsubsection{Total ozone column}

All three tests confirmed the presence of a significant change point around March 1998 in the time series of monthly anomalies of $Q_{\mathrm{O}_{3}}$, where the mean before the change point is clearly lower than the one after the change point (Fig. 6). As there is clearly more than one general trend within the 


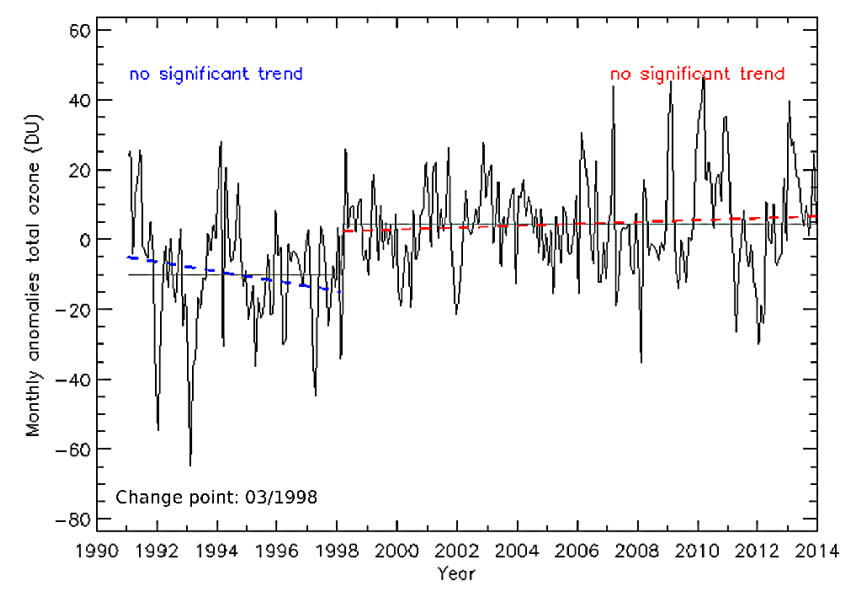

Figure 6. The black line represents the time series of monthly anomalies of total ozone column (1991-2013). The blue (dashed) line represents the (insignificant) negative trend before the detected change point, and the red (dashed) line represents the (insignificant) positive trend after the change point. The grey lines represent the mean before and after the change point.

entire time series, there is no need for detrending in this case. There was no change in the calibration constants of the Brewer instrument around 1998, so the change point has no known instrumental cause. To further exclude an instrumental cause for the step change in the mean of the Uccle ozone time series, we investigated the total ozone time series of De Bilt (the Netherlands; $52.10^{\circ} \mathrm{N} / 5.18^{\circ} \mathrm{E}$; data obtained from www.woudc.org). This time series is also characterized by a step change and change point in the beginning of 1998 (March 1998). At that time, there was no change in the calibration constants of the Brewer instrument at De Bilt. This confirms that the change point seen in the Uccle time series must have a natural/environmental cause.

\subsubsection{Aerosol optical depth at $320.1 \mathrm{~nm}$}

According to the change-point analysis, no significant change was found in the mean of the monthly anomalies of $\tau_{\text {aer. }}$.

\subsubsection{Overview and explanations}

The change points in the time series of $S_{\text {ery }}$ and $Q_{\mathrm{O}_{3}}$ occur around the same time period (February/March 1998). Since we were able to rule out known instrumental causes for the detected change points in both time series, we can assume that they have some natural/environmental cause and are related to each other.

The change point in the $Q_{\mathrm{O}_{3}}$ time series corresponds with results found in the literature. Recent studies have shown that, for other stations, the ozone recovery started around 1997 (Steinbrecht et al., 2006; Reinsel et al., 2005). Ozone levels seem to follow the change in chlorine concentrations resulting from the regulations of the Montreal Protocol in 1987. When ozone starts to increase, it is expected to have some implications on the UV irradiance as ozone is a strong absorber of UV irradiance in the stratosphere (Wenny et al., 2001). An increase in ozone would normally lead to a decrease in UV irradiance, which is not what was observed at Uccle, where the UV irradiance levels continue to increase after 1998. Before 1998, the (insignificant) trends in the time series of $Q_{\mathrm{O}_{3}}$ and $S_{\text {ery }}$ are opposite, which is what would be expected. However, after 1998, both the (insignificant) $Q_{\mathrm{O}_{3}}$ and $S_{\text {ery }}$ trend are positive. So the behavior of $Q_{\mathrm{O}_{3}}$ can only partly explain the changes observed in the UV irradiance time series, and other parameters, such as aerosols and cloudiness, might play an important role.

\subsection{Multiple linear regression analysis}

Before applying the MLR technique, it has to be verified that the explanatory variables $\left(S_{\mathrm{g}}, Q_{\mathrm{O}_{3}}\right.$ and $\left.\tau_{\text {aer }}\right)$ are independent variables. This is done by calculating the correlation coefficients between these parameters. The correlation coefficients between the three variables are low enough $(<0.25)$ to allow using these variables as independent explanatory variables for the multiple regression analysis. As opposed to the previous analysis methods, the MLR is applied to daily values, instead of monthly anomaly values. For $S_{\text {ery }}$ and $S_{\mathrm{g}}$, the daily sums are used, whereas for $Q_{\mathrm{O}_{3}}$ and $\tau_{\text {aer }}$ daily mean values are used.

\subsubsection{MLR analysis of daily values using total ozone column, global solar radiation and aerosol optical depth}

The MLR analysis has been applied to 1246 simultaneous daily values of erythemal UV dose $\left(S_{\text {ery }}\right)$, global solar radiation $\left(S_{\mathrm{g}}\right)$, total ozone $\left(Q_{\mathrm{O}_{3}}\right)$ and aerosol optical depth $\left(\tau_{\mathrm{aer}}\right)$ between 1991 and 2008. The amount of regression days was highly limited by the available $\tau_{\text {aer }}$ measurements. The resulting regression equation is

$S_{\text {ery }}=690+0.000169 \times S_{\mathrm{g}}-5.01 \times Q_{\mathrm{O}_{3}}+70.0 \times \tau_{\text {aer }}+\epsilon$

(with $S_{\text {ery }}$ in $\mathrm{J} \mathrm{m}^{-2}$; $S_{\mathrm{g}}$ in $\mathrm{J} \mathrm{m}^{-2}$; and $Q_{\mathrm{O}_{3}}$ in DU).

The adjusted $R^{2}$ value of the multiple regression is 0.94 , which means that $S_{\mathrm{g}}, Q_{\mathrm{O}_{3}}$ and $\tau_{\text {aer }}$ together explain $94 \%$ of the variation in daily $S_{\text {ery }}$. The changes in $S_{\text {ery }}$ caused by the variation of each of the three parameters can be calculated by multiplying the standard deviation of each parameter with its corresponding regression coefficient and dividing this by the average $S_{\text {ery }}$ value. From the results, it is clear that $S_{\mathrm{g}}$, whose variation leads to a change in $S_{\text {ery }}$ of $56 \%$, has the biggest influence on $S_{\text {ery }}$, followed by $Q_{\mathrm{O}_{3}}$ (change in $S_{\text {ery }}$ of $-9 \%$ ) and $\tau_{\text {aer }}$ (change in $S_{\text {ery }}$ of $1 \%$ ).

The data from 2009-2013 are used to validate the model (see Fig. 7). The regression equation between the modeled and measured $S_{\text {ery }}$ values $(f(x)=0.93 x+113.45$ with $x$ : 
Table 9. Performance of the seasonal regression models.

\begin{tabular}{ccccc}
\hline & Spring & Summer & Autumn & Winter \\
\hline Correlation & 0.95 & 0.93 & 0.97 & 0.90 \\
Regression equation & $y=0.89 x+145.17$ & $y=0.94 x+104.36$ & $y=0.90 x+102.48$ & $y=0.91 x+8.13$ \\
MBE & $-4 \%$ & $-2 \%$ & $0.06 \%$ & $-7 \%$ \\
MABE & $14 \%$ & $6 \%$ & $15 \%$ & $15 \%$ \\
\hline
\end{tabular}

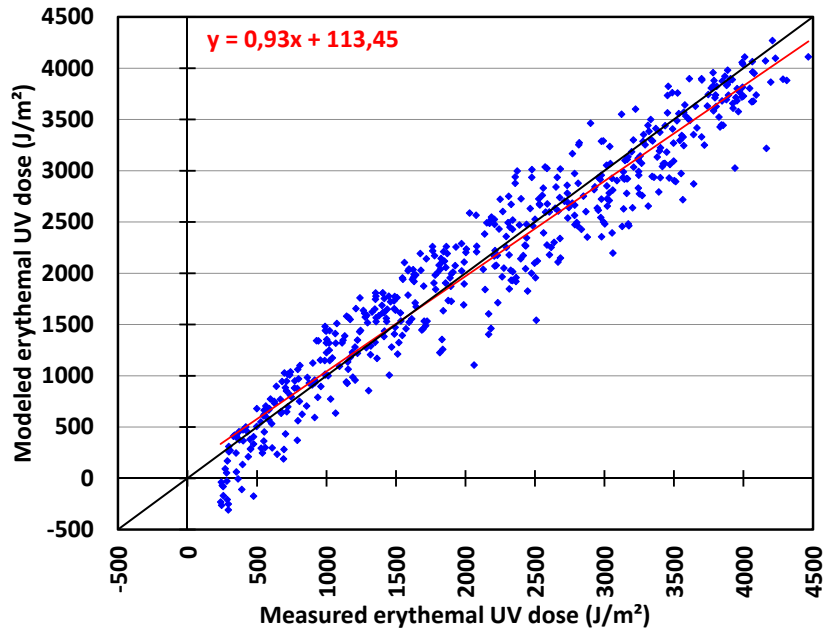

Figure 7. Scatterplot of the measured and modeled erythemal UV doses at Uccle for the 2009-2013 validation period. The red line represents the regression line of the data $(f(x)=0.93 x+113.45)$. The black line is the $f(x)=x$ line.

measured values) and the correlation coefficient (0.96) reveal the good agreement between model and reality. The MBE of the model is $-3 \%$, meaning that the model has a slight tendency to underestimate the measurements, which can be seen in Figs. 7 and 8. The MABE, which is a useful measure to evaluate the overall performance of the model, equals $18 \%$. This means that the model proposed here estimates the $S_{\text {ery }}$ with a mean error of $18 \%$. Figure 7 and the upper panel of Fig. 8 show that, in some cases, negative $S_{\text {ery }}$ doses are modeled, which is a sign that the model does not always give realistic results. This is the case only during winter, when the $S_{\mathrm{g}}$ values are much lower than during the other seasons. When moderate to high $Q_{\mathrm{O}_{3}}$ values are combined with low $S_{\mathrm{g}}$ values, this leads to negative modeled $S_{\text {ery }}$ values according to the regression equation. From Fig. 8 it is also clear that there is a seasonal cycle in the residual values. Therefore, it would be better to perform the multiple regression analysis on a seasonal scale.

\subsubsection{Seasonal MLR analysis using total ozone column, global solar radiation and aerosol optical depth}

The multiple regression equations for the different seasons are presented below.

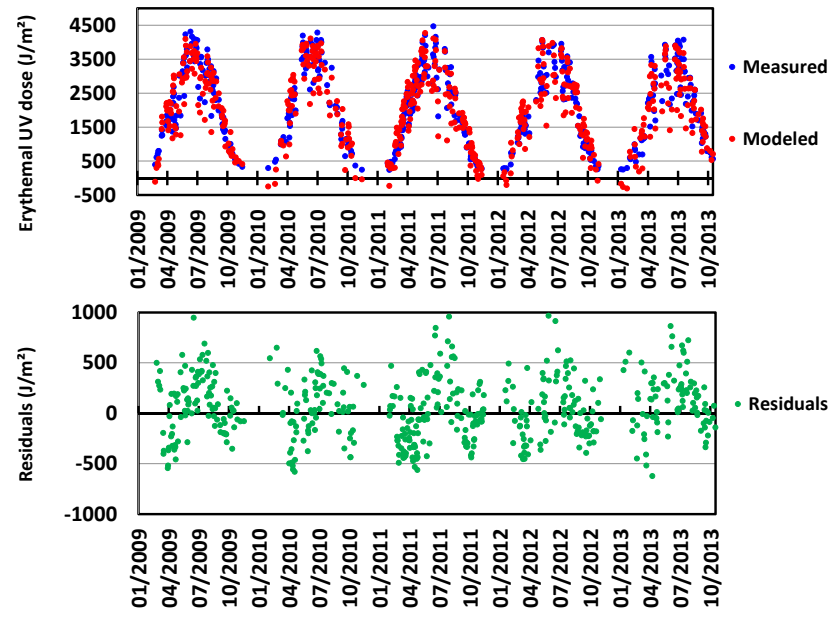

Figure 8. Validation of the multiple linear regression equation: the upper panel shows the measured (in blue) and modeled (in red) erythemal UV values; the lower panel presents the absolute residuals.

Spring:

$S_{\text {ery }}=1016+0.0001542 \times S_{\mathrm{g}}-5.660 \times Q_{\mathrm{O}_{3}}+92.11 \times \tau_{\text {aer }}+\epsilon$

Summer:

$S_{\text {ery }}=2010+0.0001481 \times S_{\mathrm{g}}-6.737 \times Q_{\mathrm{O}_{3}}-134.2 \times \tau_{\text {aer }}+\epsilon$

Autumn:

$S_{\text {ery }}=-195+0.000143 \times S_{\mathrm{g}}-1.22 \times Q_{\mathrm{O}_{3}}+120 \times \tau_{\mathrm{aer}}+\epsilon$

Winter:

$S_{\text {ery }}=325+0.0000750 \times S_{\mathrm{g}}-1.50 \times Q_{\mathrm{O}_{3}}+101 \times \tau_{\mathrm{aer}}+\epsilon$

For all seasons, more than $80 \%$ of the total variation in $S_{\text {ery }}$ is explained by the combination of $S_{\mathrm{g}}, Q_{\mathrm{O}_{3}}$ and $\tau_{\mathrm{aer}}$. This could be concluded from the adjusted $R^{2}$ values for each season. What might seem strange is the negative value of the constant term in the regression equation for autumn. However, the $p$ value for this term is higher than 0.05 , which means that this coefficient does not significantly differ from 0 at the $95 \%$ significance level.

From Fig. 9 and Table 9, it can be concluded that the seasonal models perform well in estimating the measured $S_{\text {ery }}$ values. The correlation between the modeled and measured 

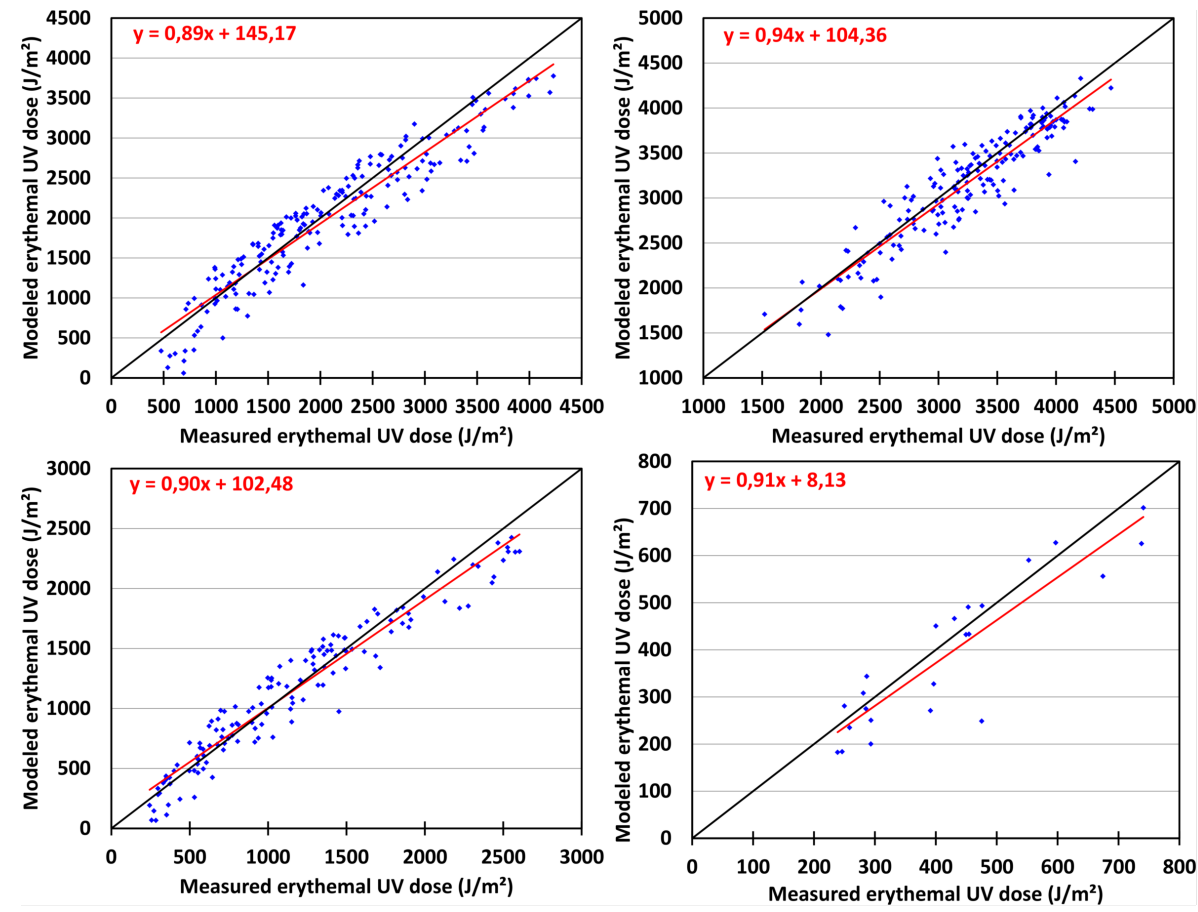

Figure 9. Scatterplots of the measured and modeled erythemal UV doses at Uccle for the 2009-2013 validation period for spring (upper left panel), summer (upper right panel), autumn (lower left panel) and winter (lower right panel). The red lines represent the regression lines of the data, and the black lines are the $f(x)=x$ lines.

Table 10. Seasonal influence of the variation of $S_{\mathrm{g}}, Q_{\mathrm{O}_{3}}$ and $\tau_{\mathrm{aer}}$ on $S_{\text {ery. }}$.

\begin{tabular}{lrrrr}
\hline & Spring & Summer & Autumn & Winter \\
\hline$\tau_{\text {aer }}$ & $1 \%$ & $-1 \%$ & $2 \%$ & $4 \%$ \\
$Q_{\mathrm{O}_{3}}$ & $-9 \%$ & $-4 \%$ & $-2 \%$ & $-15 \%$ \\
$S_{\mathrm{g}}$ & $37 \%$ & $18 \%$ & $53 \%$ & $32 \%$ \\
\hline
\end{tabular}

values varies between 0.90 (in winter) and 0.97 (in autumn). The regression equations are shown in both Fig. 9 and Table 9. The negative MBE values (except for autumn, which has a value close to 0 ) show that each model has a tendency to underestimate the measured values. The summer model performs best, with an absolute mean model error of only $6 \%$. The relative residuals (shown in Fig. 10) are smallest in summer, which again points out that the performance of the summer model in estimating the measured $S_{\text {ery }}$ is the best. The spring and autumn models have much higher relative residuals.

To determine the influence of the variation in the parameters on the variation in UV, the standard deviation of each parameter is multiplied with its corresponding regression coefficient, which is then divided by the average $S_{\text {ery }}$ value. This will give an idea of the magnitude of the influence of each parameter on UV. The results are given in Table 10. Changes in the variation of $S_{\mathrm{g}}$ (Table 10) are the most important and

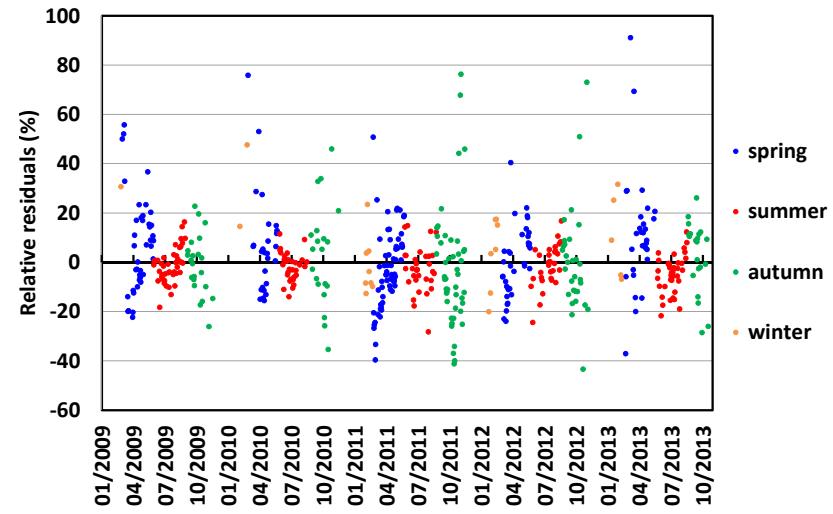

Figure 10. Relative residuals (= (measured-modeled) / measured $\times 100)$ of the seasonal multiple regression models. The colors represent the different seasons: blue - spring; red - summer; green autumn; and orange - winter.

lead to changes in $S_{\text {ery }}$ between $18 \%$ (in summer) and $53 \%$ (in autumn). The influence of the variation in $Q_{\mathrm{O}_{3}}$ and $\tau_{\text {aer }}$ is much smaller. Changes in the variation of $Q_{\mathrm{O}_{3}}$ always lead to negative changes in $S_{\text {ery }}$ (from $-2 \%$ in summer to $-15 \%$ in winter), whereas the influence of a change in variation of

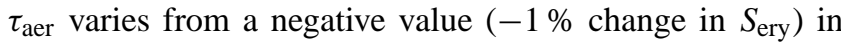
summer to positive values in the other seasons, with a maximum of $4 \%$ in winter (Table 10$). \tau_{\text {aer }}$ and $S_{\mathrm{g}}$ have their low- 
est contribution in summer. $Q_{\mathrm{O}_{3}}$ on the other hand has the lowest contribution in autumn. The influence of $Q_{\mathrm{O}_{3}}$ is highest during winter and spring, and this is in accordance with the variation in $Q_{\mathrm{O}_{3}}$ itself, which is largest during winter and early spring. For $\tau_{\text {aer }}$ also, the absolute contribution to the variation in $S_{\text {ery }}$ is the highest in winter. As the path length of UV irradiance is higher during winter, aerosols and ozone have more opportunity to influence UV irradiance on its way to the Earth's surface.

The influence of $\tau_{\text {aer }}$ on $S_{\text {ery }}$ in the seasonal models is positive (except in summer), which is also the case when the $\tau_{\text {aer }}$ is used as the only explanatory variable in the models. This does not agree with what was observed in the trend analysis of the monthly anomalies time series, where an increase in $S_{\text {ery }}$ is accompanied by a decrease in $\tau_{\text {aer. }}$. It has to be taken into account, however, that the negative general $\tau_{\text {aer }}$ trend is not significant. Also, this negative trend in $\tau_{\text {aer }}$ is too much driven by the high but sparse values at the beginning of the studied time period. Depending on the circumstances and the physical and optical properties of aerosols, the influence of $\tau_{\text {aer }}$ on global and UV irradiance can be either positive or negative. An increase in $\tau_{\text {aer }}$ could lead to an increase in global and UV radiation if the increase in $\tau_{\text {aer }}$ were caused by an increase in the amount of small scattering aerosol particles. If there were predominantly particles of size much smaller than the UV wavelengths (i.e., freshly formed particles, Aitken mode particles) and of high singlescattering albedo (SSA), the UV radiation could be enhanced by the multiple scattering by these aerosols. However, if the amount of all particles exceeded a certain (albeit in this study not possible to determine) threshold value, extinction would take over, and from this point an increase in $\tau_{\text {aer }}$ would lead to a decrease in UV irradiance. The aerosol composition, which determines whether a mixture is rather scattering or absorbing, the aerosol amount and the aerosol size distribution determine whether an increase in $\tau_{\text {aer }}$ will lead to either an increase or decrease in UV irradiance. At Uccle there is no information on these parameters; hence it is difficult to unambiguously characterize the influence of $\tau_{\text {aer }}$ on UV irradiance. The aerosol effects on UV in this study are solely based on $\tau_{\text {aer }}$ and not on aerosol absorption property changes. Recently, a nephelometer and an aethalometer have been installed at our site in Uccle, so in the future their measurements can be combined to derive the SSA. This will shine a new light on the influence of the aerosols on the UV radiation at Uccle. Antón et al. (2011) already reported that it is hard to determine the effect of aerosols due to their temporal and spatial variability and the difficulties associated with their characterization.

It has already been shown that $S_{\mathrm{g}}$ has the largest influence on $S_{\text {ery }}$, so an important issue that needs to be addressed is whether $Q_{\mathrm{O}_{3}}$ and $\tau_{\text {aer }}$ are actually necessary to capture the variation in $S_{\text {ery }}$. This was investigated by performing the MLR analysis using (1) only $S_{\mathrm{g}},(2) S_{\mathrm{g}}$ combined with $Q_{\mathrm{O}_{3}}$ and (3) $S_{\mathrm{g}}$ combined with $\tau_{\text {aer }}$ as explanatory variables. The
Table 11. Results of MLR analysis with only $S_{\mathrm{g}}, S_{\mathrm{g}}$ combined with $Q_{\mathrm{O}_{3}}$ and $S_{\mathrm{g}}$ combined with $\tau_{\mathrm{aer}}$ as explanatory variables.

\begin{tabular}{lccc}
\hline & $S_{\mathrm{g}}$ & $S_{\mathrm{g}}+Q_{\mathrm{O}_{3}}$ & $S_{\mathrm{g}}+\tau_{\mathrm{aer}}$ \\
\hline Adjusted $R^{2}$ & & & \\
\hline Spring & 0.85 & 0.90 & 0.85 \\
Summer & 0.81 & 0.85 & 0.81 \\
Autumn & 0.95 & 0.95 & 0.95 \\
Winter & 0.65 & 0.81 & 0.65 \\
\hline MABE (in \%) & & & \\
\hline Spring & 14.53 & 14.40 & 14.33 \\
Summer & 6.39 & 6.21 & 6.21 \\
Autumn & 15.45 & 15.25 & 14.89 \\
Winter & 22.20 & 14.25 & 21.47 \\
\hline Correlation modeled and & & & \\
measured UV values & & & \\
\hline Spring & 0.93 & 0.95 & 0.93 \\
Summer & 0.91 & 0.93 & 0.91 \\
Autumn & 0.96 & 0.96 & 0.96 \\
Winter & 0.75 & 0.89 & 0.76 \\
\hline
\end{tabular}

adjusted $R^{2}$ value, the MABE and the correlation between modeled and measured $S_{\text {ery }}$ values are given in Table 11 . From these values, it becomes clear that $\tau_{\text {aer }}$ only has a minor contribution to the regression model and that, to describe the changes in $S_{\text {ery }}, \tau_{\text {aer }}$ might not be needed, except perhaps for spring. For this reason it seems unnecessary to include $\tau_{\text {aer }}$ in the MLR analysis. $Q_{\mathrm{O}_{3}}$ seems to be a more important explanatory variable, as the adjusted $R^{2}$ increases for all seasons, except summer, and the MABE of the models decreases, except in summer, when combining $S_{\mathrm{g}}$ and $Q_{\mathrm{O}_{3}}$. The correlation between modeled and measured values does not change much, except in winter (from 0.75 when using only $S_{\mathrm{g}}$ to 0.89 when combining $S_{\mathrm{g}}$ and $Q_{\mathrm{O}_{3}}$ ). The developed regression models are only valid for Uccle. For other sites, it might be necessary to include all three parameters in the regression models in order to explain the observed variation in $S_{\text {ery. }}$

\section{Conclusions}

Of the variables known to influence the UV irradiance that reaches the ground, the variability of global solar radiation, total ozone column and aerosol optical depth (at $320.1 \mathrm{~nm}$ ) are studied by performing a trend analysis, a change-point analysis and a multiple linear regression analysis. This is done in order to determine their changes over a 23 year time period (1991-2013) and their possible relation to the observed UV changes at Uccle, Belgium. $S_{\text {ery }}, Q_{\mathrm{O}_{3}}$ and $\tau_{\text {aer }}$ are measured by the Brewer spectrophotometer instruments, and $S_{\mathrm{g}}$ measurements are performed by a CM11 pyranometer. 
The trend over the past 23 years was determined for each variable using their monthly anomaly values. An overall positive trend was present in the time series of $S_{\text {ery }}, S_{\mathrm{g}}$ and $Q_{\mathrm{O}_{3}}$ of respectively $+7 \%( \pm 2 \%),+4 \%( \pm 1 \%)$ and $+2.6 \%$ $( \pm 0.4 \%)$ per decade. In contrast, the trend of $\tau_{\text {aer }}$, equal to $-8 \%( \pm 5 \%)$ per decade, is insignificantly negative over the investigated time period. The sign and magnitude of the trends observed at Uccle agree with results found in the literature for stations of comparable latitude. The increase in $S_{\mathrm{g}}$ since 1991 could be interpreted as a sign of continuing global brightening over Belgium. The decrease in sulfur and black carbon emissions after 1989, which resulted in enhanced global solar radiation at the Earth's surface, is most probably also the driving mechanism for the decrease in $\tau_{\text {aer }}$, which in turn could have an influence by increasing the UV irradiance.

For both $S_{\text {ery }}$ and $S_{\mathrm{g}}$, there is an increase in the frequency of higher values towards the second part of the study period (2003-2013), without the entire frequency distribution shifting. This could be explained by a decrease in cloudiness towards 2003-2013. Several studies report on a decrease in cloud cover over the past decades and a tendency for cumuliform clouds to replace stratiform clouds (Norris and Slingo, 2009; Eastman and Warren, 2013). This would increase both $S_{\mathrm{g}}$ and $S_{\text {ery }}$ due to enhanced scattering. However, other parameters (such as ozone and aerosols) could also influence the values of $S_{\text {ery }}$ and $S_{\mathrm{g}}$. As opposed to $S_{\text {ery }}$ and $S_{\mathrm{g}}$, a clear shift can be seen in the entire frequency distribution of daily $Q_{\mathrm{O}_{3}}$ values, with both minimum and maximum values having increased from the 1991-2002 period to the 2003-2013 period, which supports literature findings about an ozone recovery around the end of the 1990s. From the frequency distribution of daily $\tau_{\text {aer }}$ values, it can be derived that, between 1991 and 2002, higher $\tau_{\text {aer }}$ values were more frequently present than during the last period (2003-2013), which is in agreement with the overall decrease over the last 23 years.

The seasonal trends of the four variables were also studied and are similar between $S_{\text {ery }}$ and $S_{\mathrm{g}}$, with a positive trend for all seasons except winter. The $Q_{\mathrm{O}_{3}}$ trend is positive for spring and summer. Normally, we would expect a positive $Q_{\mathrm{O}_{3}}$ trend to be accompanied with a negative trend in $S_{\text {ery }}$. The fact that the observed trends have the same sign could indicate that the change in UV irradiance is not only influenced by a change in total ozone values. The $\tau_{\text {aer }}$ trend is negative during summer and autumn. The trend in spring is not significant, and not enough winter data were present to calculate a winter trend.

For $Q_{\mathrm{O}_{3}}$ and $S_{\text {ery }}$, a significant change point (i.e., a significant shift in the mean of the monthly anomalies) was detected around February/March 1998, which has no known instrumental cause. The timing of the change point in ozone corresponds to results found in the literature where studies define the change around this time period as the start of ozone recovery, following the regulations of the Montreal Protocol.
The trend in the ozone time series at Uccle does not seem very affected by the eruption of the Pinatubo, which took place in June 1991.

To investigate the influences of $S_{\mathrm{g}}, Q_{\mathrm{O}_{3}}$ and $\tau_{\mathrm{aer}}$ on $S_{\text {ery }}$, a multiple linear regression was performed using daily values between 1991 and 2008. The three variables together explain $94 \%$ of the total variation in the observed $S_{\text {ery }}$ values. $S_{\mathrm{g}}$ has the largest influence on $S_{\text {ery }}$, followed by $Q_{\mathrm{O}_{3}}$ and $\tau_{\text {aer }}$. Data of 2009-2013 were used to validate the model, and the MBA and MABE were calculated to evaluate the model performance in terms of overestimation and average error. The MBE value of the model is $-3 \%$, which means that the model has a slight tendency to underestimate the measured UV irradiance values. The average error of the model in the estimation of the measurements is equal to $18 \%$. Overall, the model represents reality well; however sometimes during winter, negative $S_{\text {ery }}$ values were modeled. For this reason, seasonal regression models have been developed.

All seasonal models perform rather well in explaining the variation in UV irradiance, with adjusted $R^{2}$ values being larger than 0.8 . The negative MBE values show the models' tendencies to underestimate UV irradiance. Again, $S_{\mathrm{g}}$ has the largest influence on $S_{\text {ery }}$, followed by $Q_{\mathrm{O}_{3}}$ and $\tau_{\text {aer }}$. The summer regression model performs best, based on the very low MABE values.

What is seen in reality (i.e., an increase in $S_{\text {ery }}$ accompanied with an increase in $Q_{\mathrm{O}_{3}}$ and a decrease in $\tau_{\text {aer }}$ ) is not always what is represented by the models. According to the regression models, $Q_{\mathrm{O}_{3}}$ and $\tau_{\text {aer }}$ respectively always have a negative and positive influence on $S_{\text {ery }}$. However, as $S_{\mathrm{g}}$ is obviously the most important factor in explaining the variation in $S_{\text {ery }}$, the increase in $Q_{\mathrm{O}_{3}}$ (which would be expected to lead to a decrease in $S_{\text {ery }}$ ) and the change in $\tau_{\text {aer }}$ seem to be compensated for by the increase in $S_{\mathrm{g}}$.

The question that remains is whether $Q_{\mathrm{O}_{3}}$ and $\tau_{\text {aer }}$ are needed as explanatory variables in the multiple linear regression models. It has been shown that the contribution of $\tau_{\text {aer }}$ to explaining the variation in $S_{\text {ery }}$ is very small, and it can be concluded that this variable is not really needed in the multiple linear regression model. Also its influence is already partly represented by $S_{\mathrm{g}} \cdot Q_{\mathrm{O}_{3}}$, however, does seem to be a more important factor in capturing the variation in $S_{\text {ery }}$ and cannot be discarded from the regression models. It has to be kept in mind that the regression models are only valid for Uccle, which means that for other sites it might be necessary to include all three parameters in the regression models.

Acknowledgements. This research was performed under the project AGACC-II, contract SD/CS/07A, of the Belgian Science Policy. We thank Christian Hermans (Belgian Institute for Space Aeronomy, Belgium) for establishing and maintaining the AERONET site at Uccle. We would also like to thank the anonymous reviewers and the editor (S. Kazadzis) for their useful input.

Edited by: S. Kazadzis 


\section{References}

Alpert, P., Shvainshtein, O., and Kishcha, P.: AOD trends over megacities based on space monitoring using MODIS and MISR, Am. J. Clim. Change, 12, 117-131, doi:10.4236/ajcc.2012.13010, 2012.

Antón, M., Serrano, A., Cancillo, M. L., and García, J. A.: An empirical model to estimate ultraviolet erythemal transmissivity, Ann. Geophys., 27, 1387-1398, doi:10.5194/angeo-27-13872009, 2009.

Antón, M., Gil, J. E., Fernández-Gálvez, J., Lyamani, H., Valenzuela, A., Foyo-Moreno, I., Olmo, F. J., and Alados-Arboledas, L.: Evaluation of the aerosol forcing efficiency in the UV erythemal range at Granada, Spain, J. Geophys. Res., 116, D20214, doi:10.1029/2011JD016112, 2011.

Augustine, J. A., Hodges, G. B., Dutton, E. G., Michalsky, J. J., and Cornwall, C. R.: An aerosol optical depth climatology for NOAA's national surface radiation budget network (SURFRAD), J. Geophys. Res., 113, D11204, doi:10.1029/2007JD009504, 2008.

Bais, A. F., Kazadzis, S., Meleti, C., Kouremeti, N., Kaurola, J., Lakkala, K., Slaper, H., den Outer, P. N., Josefsson, W., Feister, U., and Janouch, M.: Variability in spectral UV irradiance at seven European stations, edited by: Gröbner J., One century of UV radiation research. Proceedings of the UV conference, Davos, Switzerland, July 2007, 1, 27-28, 2007.

Bais, A. F., Tourpali, K., Kazantzidis, A., Akiyoshi, H., Bekki, S., Braesicke, P., Chipperfield, M. P., Dameris, M., Eyring, V., Garny, H., Iachetti, D., Jöckel, P., Kubin, A., Langematz, U., Mancini, E., Michou, M., Morgenstern, O., Nakamura, T., Newman, P. A., Pitari, G., Plummer, D. A., Rozanov, E., Shepherd, T. G., Shibata, K., Tian, W., and Yamashita, Y.: Projections of UV radiation changes in the 21st century: impact of ozone recovery and cloud effects, Atmos. Chem. Phys., 11, 7533-7545, doi:10.5194/acp-11-7533-2011, 2011.

Bartlett, L. M. and Webb, A. R.: Changes in ultraviolet radiation in the 1990s: Spectral measurements from Reading, England, J. Geophys. Res., 105, 4889-4893, doi:10.1029/1999JD900493, 2000.

Bernhard, G., Booth, C. R., Ehramjian, J. C., and Nichol, S. E.: UV climatology at McMurdo Station, Antarctica, based on Version 2 data of the National Science Foundation's Ultraviolet Radiation Monitoring Network, J. Geophys. Res., 111, D11201, doi:10.1029/2005JD005857, 2006.

Bojkov, R. D., Bishop, L., and Fioletov, V. E.: Total ozone trends from quality-controlled ground-based data (1964-1994), J. Geophys. Res., 100, 25867-25876, doi:10.1029/95JD02907, 1995.

Cheymol, A. and De Backer, H.: Retrieval of the aerosol optical depth in the UV-B at Uccle from Brewer ozone measurements over a long time period 1984-2002, J. Geophys. Res., 108, 4800, doi:10.1029/2003JD003758, 2003.

Chiaccio, M., Ewen, T., Wild, M., Chin, M., and Diehl, T.: Decadal variability of aerosol optical depth in Europe and its relationship to the temporal shift of the North Atlantic Oscillation in the realm of dimming and brightening, J. Geophys. Res., 116, D02108, doi:10.1029/2010JD014471, 2011.

Chubarova, N. Y.: UV variability in Moscow according to long term UV measurements and reconstruction model, Atmos. Chem. Phys., 8, 3025-3031, doi:10.5194/acp-8-3025-2008, 2008.
Cordero, R. R., Seckmeyer, G., Pissulla, D., and Labbe, F.: Exploitation of spectral direct UV irradiance measurements, Metrologia, 46, 19-25, doi:10.1088/0026-1394/46/1/003, 2009.

De Backer, H.: Time series of daily erythemal UV doses at Uccle, Belgium, Int. J. Remote Sens., 30, 4145-4145, doi:10.1080/01431160902825032, 2009.

De Backer, H. and De Muer, D.: Intercomparison of total ozone data measured with Dobson and Brewer ozone spectrophotometers at Uccle (Belgium) from January 1984 to March 1991, including zenith sky observations, J. Geophys. Res., 96, 20711-20719, doi:10.1029/91JD02159, 1991.

De Bock, V., De Backer, H., Mangold, A., and Delcloo, A.: Aerosol optical depth measurements at $340 \mathrm{~nm}$ with a Brewer spectrophotometer and comparison with Cimel sunphotometer observations at Uccle, Belgium, Atmos. Meas. Tech., 3, 1577-1588, doi:10.5194/amt-3-1577-2010, 2010.

de La Casinière, A., Lamine Touré, M., Masserot, D., Cabot, T., and Pinedo Vega, J. L.: Daily doses of biologically active UV radiation retrieved from commonly available parameters, Photochem. Photobiol., 76, 171-175, doi:10.1562/00319655(2002)0760171DDOBAU2.0.002, 2002.

de Meij, A., Pozzer, A., and Lelieveld, J.: Trend analysis in aerosol optical depths and pollutant emission estimates between 2000 and 2009, Atmos. Environ., 51, 75-85, doi:10.1016/j.atmosenv.2012.01.059, 2012.

den Outer, P. N., Slaper, H., Matthijsen, J., Reinen, H. A. J. M., and Tax, R.: Variability of ground-level ultraviolet: Model and Measurement, Radiat. Prot. Dos., 91, 105-110, 2000.

den Outer, P. N., Slaper, H., Kaurola, J., Lindfors, A., Kazantzidis, A., Bais, A. F., Feister, U., Junk, J., Janouch, M., and Josefsson, W.: Reconstructing of erythemal ultraviolet radiation levels in Europe for the past 4 decades, J. Geophys. Res., 115, D10102, doi:10.1029/2009JD012827, 2010.

Díaz, S., Deferrari, G., Martinioni, D., and Oberto, A.: Regression analysis of biologically effective integrated irradiances versus ozone, clouds and geometric factors, J. Atmos. Sol-Terr. Phy., 62, 629-638, doi:10.1016/S1364-6826(00)00055-9, 2000.

Diffey, B. L.: Solar ultraviolet radiation effects on biological systems, Phys. Med. Biol., 36, 299-328, doi:10.1088/00319155/36/3/001, 1991

Durbin, J. and Watson, G. S.: Testing for serial correlation in least squares regression III, Biometrika, 58, 1-19, 1971.

Eastman, R. and Warren, S. G.: A 39-yr survey of cloud changes from land stations worldwide 1971-2009: long-term trends, relation to aerosols and expansion of the tropical belt, J. Climate, 26, 1286-1303, doi:10.1175/JCLI-D-12-00280.1, 2013.

Eck, T. F., Holben, B. N., Reid, J. S., Dubovik, O., Smirnov, A., O'Neill, N. T., Slutsker, I., and Kinne, S.: Wavelength dependence of the optical depth of biomass burning, urban, and desert dust aerosols, J. Geophys. Res., 104, 31333-31349, doi:10.1029/1999JD900923, 1999.

Eleftheratos, K., Kazadzis, S., Zerefos, C. S., Tourpali, K., Meleti, C., Balis, D., Zyrichidou, I., Lakkala, K., Feister, U., Koskela, T., Heikkilä, A., and Karhu, J. M.: Ozone and Spectroradiometric UV Changes in the Past 20 Years over High Latitudes, Atmos.Ocean, doi:10.1080/07055900.2014.919897, 2014.

El Shazly, S. M., Kassem, Kh. O., Hassan, A. A., and ElNobi, E. F.: An empirical model to estimate UV index in 
some upper Egypt regions, Resour. Environ., 2, 216-227, doi:10.5923/j.re.20120205.05, 2012.

Fioletov, V. E., McArthur, L. J. B., Kerr, J. B., and Wardle, D. I.: Long-term variations of UV-B irradiance over Canada estimated from Brewer observations and derived from ozone and pyranometers measurements, J. Geophys. Res., 106, 23009-23027, doi:10.1029/2001JD000367, 2001.

Fioletov, V. E., Kerr, J. B., Wardle, D. I., Krotkov, N., and Herman, J. R.: Comparison of Brewer ultraviolet irradiance measurements with total ozone mapping spectrometer satellite retrievals, Opt. Eng., 41, 3051-3061, doi:10.1117/1.1516818, 2002.

Fioletov, V. E., Kimlin, M. G., Krotkov, N., McArthur, L. J. B., Kerr, J. B., Wardle, D. I., Herman, J. R., Meltzer, R., Mathews, T. W., and Kaurola, J.: UV index climatology over the United States and Canada from ground-based and satellite estimates, J. Geophys. Res., 109, D22308, doi:10.1029/2004JD004820, 2004.

Fitzka, M., Simic, S., and Hadzimustafic, J.: Trends in spectral UV radiation from long-term measurements at Hoher Sonnblick, Austria, Theor. Appl. Climatol., 110, 585-593, doi:10.1007/s00704-012-0684-0, 2012.

Foyo-Moreno, I., Alados, I., and Alados-Arboledas, L.: Adaptation of an empirical model for erythemal ultraviolet irradiance, Ann. Geophys., 25, 1499-1508, doi:10.5194/angeo-251499-2007, 2007.

Garane, K., Bais, A. F., Kazadzis, S., Kazantzidis, A., and Meleti, C.: Monitoring of UV spectral irradiance at Thessaloniki (1990-2005): data re-evaluation and quality control, Ann. Geophys., 24, 3215-3228, doi:10.5194/angeo-24-3215-2006, 2006.

Glandorf, M., Arola, A., Bais, A., and Seckmeyer, G.: Possibilities to detect trends in spectral UV irradiance, Theor. Appl. Climatol., 81, 33-44, doi:10.1007/s00704-004-0109-9, 2005.

Gröbner, J. and Meleti, C.: Aerosol optical depth in the UVB and visible wavelength range from Brewer spectrophotometer direct irradiance measurements: 1991-2002, J. Geophys. Res., 109, D09202, doi:10.1029/2003JD004409, 2004.

Gröbner, J., Kazadzis, S., Schreder, J., Bolsée, D., Brogniez, C., De Backer, H., Di Sarra, A. G., Feister, U., Görts, P., Henriques, D., Jaroslawski, J., Simic, S., Stanec, M., Steinmetz, M., Tax, R., and Villaplana Guerrero, J. M.: Report of site visits round 2004, European Commission, Joint Research Centre, EUR 21398 EN, 171-182, 2004.

Harris, N. R. P., Kyrö, E., Staehelin, J., Brunner, D., Andersen, S.B., Godin-Beekmann, S., Dhomse, S., Hadjinicolaou, P., Hansen, G., Isaksen, I., Jrrar, A., Karpetchko, A., Kivi, R., Knudsen, B., Krizan, P., Lastovicka, J., Maeder, J., Orsolini, Y., Pyle, J. A., Rex, M., Vanicek, K., Weber, M., Wohltmann, I., Zanis, P., and Zerefos, C.: Ozone trends at northern mid- and high latitudes - a European perspective, Ann. Geophys., 26, 1207-1220, doi:10.5194/angeo-26-1207-2008, 2008.

Herman, J. R.:, Global increase in UV irradiance during the past 30 years (1979-2008) estimated from satellite data, J. Geophys. Res., 115, D04203, doi:10.1029/2009JD012219, 2010.

Herman, J. R., Bhartia, P. K., Ziemke, J., Ahmad, Z., and Larko, D.: UV-B increases (1979-1992) from decreases in total ozone, Geophys. Res. Lett., 23, 2117-2120, doi:10.1029/96GL01958, 1996.

Holben, B. N., Tanré, D., Smirnov, A., Eck, T. F., Slutsker, I., Abuhassan, N., Newcomb, W. W., Schafer, J. S., Chatenet, B., Lavenu, F., Kaufman, Y. J., Vande Castle, J., Setzer, A.,
Markham, B., Clark, D., Frouin, R., Halthore, R., Karneli, A., O’Neill, N. T., Pietras, C., Pinker, R. T., Voss, K., and Zibordi, G.: An emerging ground-based aerosol climatology: Aerosol optical depth from AERONET, J. Geophys. Res., 106, 12067-12097, doi:10.1029/2001JD900014, 2001.

Hoppe, H. and Kiely, G.: Precipitation over Ireland: observed change since 1940, Phys. Chem. Earth B, 24, 91-96, 1999.

Hsu, N. C., Gautam, R., Sayer, A. M., Bettenhausen, C., Li, C., Jeong, M. J., Tsay, S.-C., and Holben, B. N.: Global and regional trends of aerosol optical depth over land and ocean using SeaWiFS measurements from 1997 to 2010, Atmos. Chem. Phys., 12, 8037-8053, doi:10.5194/acp-12-8037-2012, 2012.

Huang, M., Jiang, H., Ju, W., and Xiao, Z.: Ultraviolet radiation over two lakes in the middle and lower reaches of the Yangtze river, China: An innovative model for UV estimation, Terr. Atmos. Ocean. Sci., 22, 491-506, doi:10.3319/TAO.2011.05.02.01(A), 2011.

Journée, M. and Bertrand, C.: Improving the spatio-temporal distribution of surface solar radiation data by merging ground and satellite measurements, Remote Sens. Environ., 114, 2692-2704, doi:10.1016/j.rse.2010.06.010, 2010.

Kalliskota, S., Kaurola, J., Taalas, P., Herman, J., Celarier, E. A., and Krotkov, N. A.: Comparison of daily UV doses estimated from Nimbus 7/TOMS measurements and ground-based spectroradiometric data, J. Geophys. Res., 105, 5059-5067, doi:10.1029/1999JD900926, 2000.

Kaurola, J., Taalas, P., Koskela, T., Borkowski, J., and Josefsson, W.: Long-term variations of UV-B doses at three stations in northern Europe, J. Geophys. Res., 105, 20813-20820, doi:10.1029/2000JD900258, 2000.

Kazadzis, S., Bais, A., Amiridis, V., Balis, D., Meleti, C., Kouremeti, N., Zerefos, C. S., Rapsomanikis, S., Petrakakis, M., Kelesis, A., Tzoumaka, P., and Kelektsoglou, K.: Nine years of UV aerosol optical depth measurements at Thessaloniki, Greece, Atmos. Chem. Phys., 7, 2091-2101, doi:10.5194/acp-7-20912007, 2007.

Krishna Prasad, N. V., Niranjan, K., Sarma, M. S. S. R. K., and Madhavi, N.: Regression analysis of biologically effective UV-B irradiance versus ozone at Visakhapatnam, Int. J. Phys. Sci., 6, 7838-7843, doi:10.5897/IJPS11.581, 2011.

Krzýscin, J. W. and Borkowski, J. L.: Variability of the total ozone trend over Europe for the period 1950-2004 derived from reconstructed data, Atmos. Chem. Phys., 8, 2847-2857, doi:10.5194/acp-8-2847-2008, 2008.

Krzýscin, J. W., Sobolweski, P. S., Jaroslawski, J., Podgórski, J., and Rajewska-Wiech, B.: Erythemal UV observations at Belsk, Poland, in the period 1976-2008: data homogenization, climatology and trends, Acta Geophys., 59, 155-182, doi:10.2478/s11600-010-0036-3, 2011.

Lanzante, J. R.: Resistant, Robust and Non-parametric techniques for the analysis of climate data: theory and examples, including applications to historical radiosonde station data, Int. J. Climatol., 16, 1197-1226, doi:10.002/(SICI)10970088(199611)16:11<1197::AID-JOC89>3.0.CO;2-L, 1996.

Lindfors, A. V., Arola, A., Kaurola, J., Taalas, P., and Svenøe, T.: Longterm erythemal UV doses at Sodankylä estimated using total ozone, sunshine duration, and snow depth, J. Geophys. Res., 108, 4518, doi:10.1029/2002JD003325, 2003. 
Lindfors, A., Kaurola, J., Arola, A., Koskela, T., Lakkala, K., Josefsson, W., Olseth, J. A., and Johnsen, B.: A method for reconstruction of past UV radiation based on radiative transfer modeling: applied to four stations in northern Europe, J. Geophys. Res., 112, D23201, doi:10.1029/2007JD008454, 2007.

Litynska, Z., Koepke, P., De Backer, H., Gröbner, J., Schmalwieser, A., and Vuilleumier, L.: COST action 726 final report: Long term changes and climatology of UV radiation over Europe, ISBN 978-92-898-0052-5, Luxembourg: Publications office of the European Union, doi:10.2831/12065, 2012.

Makowski, K., Jaeger, E. B., Chiacchio, M., Wild, M., Ewen, T., and Ohmura, A.: On the relationship between diurnal temperature range and surface solar radiation in Europe, J. Geophys. Res., 114, D00D07, doi:10.1029/2008JD011104, 2009.

Matthijsen, J., Slaper, H., Reinen, A. J. M. H., and Velders, G. J. M: Reduction of solar UV by clouds: A comparison between satellite-derived cloud effects and ground-based radiation measurements, J. Geophys. Res., 105, 5069-5080, doi:10.1029/1999JD900937, 2000.

Mishchenko, M. I. and Geogdzhayev, I. V.: Satellite remote sensing reveals regional tropospheric aerosol trends, Opt. Express, 15, 7423-7438, doi:10.364/OE.15.007423, 2007.

Nabat, P., Somot, S., Mallet, M., Chiapello, I., Morcrette, J. J., Solmon, F., Szopa, S., Dulac, F., Collins, W., Ghan, S., Horowitz, L. W., Lamarque, J. F., Lee, Y. H., Naik, V., Nagashima, T., Shindell, D., and Skeie, R.: A 4D climatology (1979-2010) of the monthly tropospheric aerosol optical depth distribution over the Mediterranean region from a comparative evaluation and blending of remote sensing and model products, Atmos. Meas. Tech., 6, 1287-1314, doi:10.5194/amt-6-1287-2013, 2013.

Norris, J. R. and Slingo, A.: Chapter 2: trends in observed cloudiness and earth's radiation budget, in: Clouds in the perturbed climate system: their relationship to energy balance, atmospheric dynamics and precipitation, edited by: Heintzenberg, J. and Charlson, R. J., 2009.

Norris, J. R. and Wild, M.: Trends in aerosol radiative effects over Europe inferred from observed cloud cover, solar "dimming", and solar "brightening", J. Geophys. Res., 112, D08214, doi:10.1029/2006JD007794, 2007.

Nyeki, S., Halios, C. H., Baum, W., Eleftheriadis, K., Flentje, H., Gröbner, J., Vuilleumier, L., and Wehrli, C.: Ground-based aerosol optical depth trends at three high-altitude sites in Switzerland and southern Germany from 1995 to 2010, J. Geophys. Res., 117, D18202, doi:10.1029/2012JD017493, 2012.

Reeves, J., Chen, J., Wang, X. L., Lund, R., and Lu, Q. Q.: A review and comparison of changepoint detection techniques for climate data, J. Appl. Meteorol. Clim., 46, 900-915, doi:10.1175/JAM2493.1, 2007.

Reinsel, G. C., Miller, A. J., Weatherhead, E. C., Flynn, L. E., Nagatani, R. M., Tiao, G. C., and Wuebbles, D. J.: Trend analysis of total ozone data for turnaround and dynamical contributions, J. Geophys. Res., 110, D16306, doi:10.1029/2004JD004662, 2005.

Rieder, H. E., Holawe, F., Simic, S., Blumthaler, M., Krzyscin, J. W., Wagner, J. E., Schmalwieser, A. W., and Weihs, P.: Reconstruction of erythemal UV-doses for two stations in Austria: a comparison between alpine and urban regions, Atmos. Chem. Phys., 8, 6309-6323, doi:10.5194/acp-8-6309-2008, 2008.

Rieder, H. E., Staehelin, J., Weihs, P., Vuilleumier, L., Maeder, J. A., Holawe, F., Blumthaler, M., Lindfors, A., Peter, T., Simic,
S., Spichtinger, P., Wagner, J. E., Walker, D., and Ribatet, M.: Relationship between high daily erythemal UV doses, total ozone, surface albedo and cloudiness: An analysis of 30 years of data from Switzerland and Austria, Atmos. Res., 98, 9-20, doi:10.1016/j.atmosres.2010.03.006, 2010.

Rieder, H. E., Frossard, L., Ribatet, M., Staehelin, J., Maeder, J. A., di Rocco, S., Davison, A. C., Peter, T., Weihs, P., and Holawe, F.: On the relationship between total ozone and atmospheric dynamics and chemistry at midlatitudes - Part 2: The effects of the El Niño/Southern Oscillation, volcanic eruptions and contributions of atmospheric dynamics and chemistry to long-term total ozone changes, Atmos. Chem. Phys., 13, 165-179, doi:10.5194/acp-13165-2013, 2013.

Sanchez-Lorenzo, A. and Wild, M.: Decadal variations in estimated surface solar radiation over Switzerland since the late 19th century, Atmos. Chem. Phys., 12, 8635-8644, doi:10.5194/acp-128635-2012, 2012.

Santer, B. D., Wigley, T. M. L., Boyle, J. S., Gaffen, D. J., Hnilo, J. J., Nychka, D., Parker, D. E., and Taylor, K. E.: Statistical significance of trends and trend differences in layer-average atmospheric temperature time series, J. Geophys. Res., 105, 7337-7356, doi:10.1029/1999JD901105, 2000.

Sasaki, M., Takeshita, S., Oyanagi, T., Miyake, Y., and Sakata, T.: Increasing trend of biologically active solar ultraviolet-B irradiance in mid-latitude Japan in the 1990s, Opt. Eng., 41, 3062-3069, doi:10.1117/1.1516823, 2002.

SCI TEC: Brewer ozone spectrophotometer, Acceptance manual, Document number AM-BA-CO5-Rev C, SCI TEC Instruments, 1988.

Smedley, A. R. D., Rimmer, J. S., Moore, D., Toumi, R., and Webb, A. R.: Total ozone and surface UV trends in the United Kingdom: 1979-2008, Int. J. Climatol., 32, 338-346, doi:10.1002/joc.2275, 2012.

Solomon, S., Qin, D., Manning, M., Alley, R. B., Berntsen, T., Bindoff, N. L., Chen, Z., Chidthaisong, A., Gregory, J. M., Hegerl, G. C., Heimann, M., Hewitson, B., Hoskins, B. J., Joos, F., Jouzel, J., Kattsov, V., Lohmann, U., Matsuno, T., Molina, M., Nicholls, N., Overpeck, J., Raga, G., Ramaswamy, V., Ren, J., Rusticucci, M., Somerville, R., Stocker, T. F., Whetton, P., Wood, R. A. and Wratt, D.: Technical Summary, in: Climate Change 2007: The Physical Science Basis. Contribution of Working Group I to the Fourth Assessment Report of the Intergovernmental Panel on Climate Change, edited by: Solomon, S., Qin, D., Manning, M., Chen, Z., Marquis, M., Averyt, K. B., Tignor, M., and Miller, H. L., Cambridge University Press, Cambridge, United Kingdom and New York, NY, USA, 19-91, 2007.

Staehelin, J., Kegel, R., and Harris, N. R. P.: Trend analysis of the homogenized total ozone series of Arosa (Switzerland) 1926-1996, J. Geophys. Res., 103, 8389-8399, doi:10.1029/97JD03650, 1998.

Steinbrecht, W., Claude, H., Schönenborn, F., McDermid, I. S., Leblanc, T., Godin, S., Song, T., Swart, D. P. J., Meijer, Y. J., Bodeker, G. E., Connor, B. J., Kämpfer, N., Hocke, K., Calisesi, Y., Schneider, N., de la Noë, J., Parrish, A. D., Boyd, I. S., Brühl, C., Steil, B., Giorgetta, M. A., Manzini, E., Thomason, L. W., Zawodny, J. M., McCormick, M. P., Russell III, J. M., Bhartia, P. K., Stolarski, R. S., and Hollandsworth-Frith, S. M.: Long-term evolution of upper stratospheric ozone at selected stations of the 
Network for the Detection of Stratospheric Change (NDSC), J. Geophys. Res., 111, D1027, doi:10.1029/2005JD006454, 2006.

Stjern, C. W., Egill Kristjánsson, J., and Hansen, A. W.: Global dimming and global brightening: an analysis of surface radiation and cloud cover data in northern Europe, Int. J. Climatol., 29, 643-653, doi:10.1002/joc.1735, 2009.

Tevini, M. and Teramura, A. H.: UV-B effects on terrestrial plants, Photochem. Photobiol., 50, 479-487, doi:10.1111/j.17511097.1989.tb05552.x, 1989.

Trepte, S. and Winkler, P.: Reconstruction of erythemal UV irradiance and dose at Hohenpeissenberg (1968-2001) considering trends of total ozone, cloudiness and turbidity, Theor. Appl. Climatol., 77, 159-171, doi:10.1007/s00704-004-0034-y, 2004.

United Nations Environment Programme (UNEP): Environmental effects of ozone depletion and its interactions with climate change: 2010 assessment, 236 pp., UNEP, Nairobi, Kenya, ISBN:ISBN 92-807-2312-X, 2010.

Van Malderen, R. and De Backer, H.: A drop in upper tropospheric humidity in autumn 2001, as derived from radiosonde measurements at Uccle, Belgium, J. Geophys. Res., 115, D20114, doi:10.1029/2009JD013587, 2010.

Vigouroux, C., De Mazière, M., Demoulin, P., Servais, C., Hase, F., Blumenstock, T., Kramer, I., Schneider, M., Mellqvist, J., Strandberg, A., Velazco, V., Notholt, J., Sussmann, R., Stremme, W., Rockmann, A., Gardiner, T., Coleman, M., and Woods, P.: Evaluation of tropospheric and stratospheric ozone trends over Western Europe from ground-based FTIR network observations, Atmos. Chem. Phys., 8, 6865-6886, doi:10.5194/acp-8-6865-2008, 2008.

Weatherhead, C. E., Reinsel., G. C., Tiao, G. C., Meng, X.-L., Choi, D., Cheang, W.-K., Keller, T., DeLuisi, J., Wuebbles, D. J., Kerr, J. B., Miller, A. J., Oltmans, S. J., and Frederick, J. E.: Factors affecting the detection of trends: Statistical considerations and applications to environmental data, J. Geophys. Res., 103, 17149-17161, doi:10.1029/98JD00995, 1998.
Wenny, B. N., Saxena, V. K., and Frederick, J. E.: Aerosol optical depth measurements and their impact on surface levels of ultraviolet-B radiation, J. Geophys. Res., 106, 17311-17319, doi:10.1029/2001JD900185, 2001.

Wild, M., Trüssel, B., Ohmura, A., Long, C. N., König-Langlo, G., Dutton, E. G., and Tsvetkov, A.: Global dimming and brightening: an update beyond 2000, J. Geophys. Res., 114, D00D13, doi:10.1029/2008JD011382, 2009.

Williams, J. E., den Outer, P. N., Slaper, H., Matthijsen, J., and Kelfkens, G.: Cloud induced reduction of solar UV-radiation: A comparison of ground-based and satellite based approaches, Geophys. Res. Lett., 31, L03104, doi:10.1029/2003GL018242, 2004.

Williams, M. N., Gómez Grajales, C. A., and Kurkiewicz, D.: Assumptions of multiple regression: correcting two misconceptions, Pract. Ass. Res. Eval., 18, ISSN 1531-7714, 2013.

WMO (World Meteorological Organization), Scientific Assessment of Ozone Depletion: 2006, Global Ozone Research and Monitoring Project-Report No. 50, 572 pp., Geneva, Switzerland, 2006

Zerefos, C. S., Balis, D. S., Bais, A. F., Gillotay, D., Simon, P. C., Mayer, B., and Seckmeyer, G.: Variability of UV-B at four stations in Europe, Geophys. Res. Lett., 24, 1363-1366, 1997.

Zerefos, C., Balis, D., Tzortziou, M., Bais, A., Tourpali, K., Meleti, C., Bernhard, G., and Herman, J.: A note on the interannual variations of UV-B erythemal doses and solar irradiance from groundbased and satellite observations, Ann. Geophys., 19, 115-120, doi:10.5194/angeo-19-115-2001, 2001.

Zerefos, C. S., Tourpali, K., Eleftheratos, K., Kazadzis, S., Meleti, C., Feister, U., Koskela, T., and Heikkilä, A.: Evidence of a possible turning point in solar UV-B over Canada, Europe and Japan, Atmos. Chem. Phys., 12, 2469-2477, doi:10.5194/acp-12-24692012, 2012.

Ziemke, J. R., Chandra, S., Herman, J., and Varotsos, C.: Erythemally weighted UV trends over northern latitudes derived from Nimbus 7 TOMS measurements, J. Geophys. Res., 105, 7373-7382, 2000. 